DOI: $10.20472 / E S .2017 .6 .1 .004$

\title{
INTERESET RATE UNCERTAINTY AND FDI PRE-GLOBALISATION
}

\section{WILLIAM VUKSON}

\begin{abstract}
:
Exchange Rate uncertainty prior to the Euro were deemed an important impediment to Foreign Direct Investment Flows. This paper confirms that they were the main cause preventing optimal Private Corporate Sustainability during this era. This paper was researched with several industries in mind; automotive; textile and manufacturing sectors. It continues to serve as a key pillar for private sustainability goals in the automotive sector. Exchange Rate Uncertainty supercedes the effects of tax rate differentials and real wage rate differentials. The methodology used was OLS econometric techniques and the data was transformed into annual growth rates in order to achieve scientific compatibilities in my research methodology.
\end{abstract}

\section{Keywords:}

Exchange Rates; Uncertainty; Private Sustainability; Corporate Growth; 1970s; 1980s; Nixon, Reagan; Carter; Giscard d'Estaing; Helmut Schmidt; Snake Agreement; EMU; ERM;

JEL Classification: F21

\section{Authors:}

WILLIAM VUKSON, Centre for Automotive Sustainability, Canada, Email: g7research@eol.ca

\section{Citation:}

WILLIAM VUKSON (2017). intereset Rate Uncertainty and FDI Pre-Globalisation. International Journal of Economic Sciences, Vol. VI(1), pp. 41-78., 10.20472/ES.2017.6.1.004 


\section{INTRODUCTION}

This paper investigates real exchange rate fluctuations on foreign direct investment (FDI) for the free floating period 1974-1987. Relationships were empirically estimated for bilateral flows emanating from six European countries (Germany, Italy, Belgium-Luxembourg, France, Netherlands, U.K.) destined for the United States. Estimates obtained indicate some interestingly diverse outcomes for the individual countries considered, supporting a general theme that confirms significant negative real exchange rate effects on FDI flows.

This study was constrained by the availability of accurate and robust data for this period, thereby shortening the period of empirical inquiry from 1978 to 1987 in this paper.

The results of this paper rely on robust data and estimation techniques that OLS were able to generate with the given historical data from the U.S. Department of Commerce. The author will touch on other more modern estimation techniques in sequels to this paper and the use of the OLS estimation methodology that may not yield as robust and significant results as those that are reported here.

The research approach here benefits immensely from hindsight and in scope of the following developments prior and throughout this period:

1. The conceptualization of this period of free floating exchange rates occurred during the advent of the European Monetary System project which was to yield the establishment of the European single currency- the ECU and then the EURO.

2. The Administration of Richard Nixon and its use of the Arthur Burns Federal Reserve to its own geo-political and security goals in the Asian hemisphere and in China specifically

3 . The lack of policy co-ordination among the leading western industrialised countries from 1970 to 1986

4. The advent of the Plaza and Louvre accords between 1986 and 1988 which brought forward a conceptual framework for co-ordinating fiscal and monetary policies between $\mathrm{G} 7$ members and creating a new policy-driven perspective on how the fluctuation of real exchange rates can be better controlled.

5. The lack of any Central Banking policy independence and the targeting of inflation and expectational inflation variables throughout this period.

6. The outright politicization of the Arthur Burns and William Miller Federal Reserve regimes together with the Bank of England and the Bank of France from 1970 to 1980.

7. The conceptual lacking of any "credibility" aspects to financial markets and to monetary policies during this period of analysis and generally pre-dating any academic research in these areas.

8. The preference of having open market operations over the use of the discount window by Central Banks in general from 1970 to 1980.

9. The linking of trade to regional security interests and goals by the Nixon Administration and the rise of Japan's automotive surplus in the U.S. in the early 1980s

10. The Plaza and Louvre accords negotiated by the Reagan Administration which re-aligned the strong USD and used FDI from Japanese automakers to add industrial capacity to the domestic United States thereby instigating the first step towards what was then known as the era of "globalization."

11. The supposition that free-floating exchange rates during 1978 to 1989 were to be replaced by wage rate differentials as the prime variable in explaining FDI flows in the era of globalization. 
(paper forthcoming)

12. The rise and use of financial market engineering and offshore centres such as Barbados (see Hejazi), Bermuda, Jersey, Cyprus, etc... to mitigate financial uncertainties and risks caused by exchange rates and interest rates affecting global FDI flows. (paper forthcoming on these issues) 13. The supposition that FDI flows were driven primarily by exchange rate uncertainty preglobalisation (supported empirically in this paper) and less so during the period of "globalization" from 1990 to 2016.

14. The supposition that FDI flows were driven more by wage rate differentials and tax rate differentials from 1990 to 2016 during what we can call the "era of globalization" (empirically investigated in a forthcoming paper and as a sequel to the current paper).

The format of this paper will be segmented into four sub-sections, each dealing with a separate approach that together composes the FDI literature as a whole, as well as addressing issues that specifically pertain to the present study. For greater certainty the paper contains:

(I)

A survey and critical overview of the literature on FDI;

(II)

Theoretical constructs utilized in the present study;

(III)

Presentation of the regression model as well as the empirical estimates;

(IV)

\author{
Conclusion
}




\section{SURVEY \& CRITICAL OVERVIEW}

Theoretical developments on the issue of foreign direct investment are very recent, primarily spanning the previous four decades. Research activity in the field was stimulated by observing the emerging growth in not only international financial investment activity, but more importantly, the operation of productive assets in foreign countries. It is necessary to make this vital distinction between the two types of investment since it defines the emergence of two different approaches to (FDI) within the literature.

One can identify the relationship between the two types when placed into perspective through the application of the capital-asset pricing model (CAPM), within an international scope. Specifically, it is the work of Solnik (1974), Hartman (1979), etc. that develops the framework whereby FDI is viewed as an attempt to extract the benefits of international financial diversification. It is argued that non-financial or productive FDI will occur when financial markets are imperfect. Therefore, productive FDI serves as a substitute when financial markets are undeveloped. This would occur when a CAPM framework would be applied to a sample that would include developing countries. However, if the objective here is to restrict attention to western countries (O.E.C.D.), then the international CAPM would be applicable, being based on financial flows that are derived from efficient markets.

Furthermore, the case is frequently made that real productive activities as performed through the multinational corporation provide a better potential for the individual shareholder to effectively diversify activity. This notion is based on the observed high correlation of price-movement in the international financial markets, whereas productive investment through the multinational tie together factor and product markets that do not show a high degree of correlation in price movements. This entire development is effectively summarized by Rugman: "The tests show that international goods and factor markets (representing direct investment) are less correlated than international financial markets (representing portfolio,

i.e. purely financial investment). In turn, these results lead to the implication that an individual risk averter should purchase the shares of multinational firms, as the latter serve as indirect vehicles for desirable international diversification, which can best be achieved through the foreign operations of such firms in the goods and factor markets of the world". (1)

It is a fruitful exercise to develop the above dichotomy and reflect these developments through the present framework considering real exchange rate effects. It follows that attempts to diversify productive assets will be set back due to the potential adverse effects that real exchange rate fluctuations will have on the diversification of returns. Additional real exchange rate effects will increase the variability of the expected returns to a well-diversified multinational which will frustrate the marginal risk-averse shareholder. Consequently, if these shareholders opt to divest, then the original justification to pursue effective diversification through the real activities of a multinational will be somewhat diluted.

For the purposes of this paper, real exchange rate effects are not formally treated through the international diversification approach, although this construct is applicable when viewed as a motive to reduce the variability of total returns. Simply stated, the manager will not pursue FDI if the potential risk offsets the anticipated rate of return. In this regard, an expected utility will be maximized over the entire firm's profit function that includes both return and variability (risk) considerations. It follows from this argument that the firm could attempt to dissipate the potency 
of the additional risk factors by engaging in hedging activities. The validity of hedging vis-a-vis FDI and within context to trade considerations will be referred to throughout the paper from time to time. As well, my objective is to develop this theme fully and include it formally within the theoretical Section (II).

The weakness of the portfolio approach to FDI is that it assumes the individual investor is unable to pursue effective diversification individually. If various impediments such as real exchange rate fluctuations render international diversification ineffective, then individuals will be able to pursue an individualistic diversification policy with potentially greater returns. This will no longer provide an incentive for real FDI as is presented through the framework of this model.

However, it may be argued that FDI will always exist even if various distortions dilute the effectiveness of diversification. This idea is concisely summarized by Hartman (1979): "A more basic issue is whether it is reasonable to assume that firms minimize risk. The models are inappropriate if individual investors are able to take advantage of the gains by diversifying their portfolios, thereby eliminating the need for firms to perform the risk minimization." (2)

One of the most popular theories over the past three decades has been the 'market size hypothesis'. FDI is considered to be a function of a firm's sales in the host country, which is usually replaced by a proxy that represents the G.D.P. of the host country. The rationale for this relationship is developed on the basis of domestic experience by firms, where investment rises with sales and G.D.P. increases. The most commonly applied model in this framework is Jorgenson's model of investment expenditure. Empirically, Scaperlanda and Mauer (1969) examined the relationship using U.S. data on FDI in the E.E.C. for the period 1952-1966 and came to the conclusion that the market size hypothesis is supported statistically. Goldberg (1972) has since contradicted this result by arguing that FDI is affected by the growth of the E.E.C. market rather than absolute size (3). This study rejects the growth of U.S. G.D.P. as well as the level for the majority of the cases considered here.

In a related fashion, a more intensive survey of the impetus to invest abroad emcompasses the idea of market growth factors in a more comprehensive theory known as the 'product cycle hypothesis' primarily attributed to Vernon (1979) (4). Specifically, the life-cycle of a product is identified over three different stages of development, where the initial infant stage of production occurs in the home country in order to achieve more efficient co-ordination between it's testing in an R\&D framework and the simultaneous creation of demand through advertising. The second stage represents evolution to a mature phase where the product is prepared for export to various countries showing signs of buoyant consumption as represented by size and growth in G.D.P. Finally, as a result of expansionary demand within these host countries, FDI takes place in order to gain competitive advantage and further consolidation in these markets. The argument developed isolates such factors as real wage differentials that may provide for that necessary edge in competitive advantage.

The argument based on differential growth in wages is, however, rejected at the $1 \%$ level of significance when included in the regression equations here for every country considered. It remains that the third stage of the theory may have been directed to FDI in developing countries where the difference in wage growth patterns may turn out significant values. Furthermore, the theory has recently been criticized on the view that it is since outdated as competitive cost differences have narrowed across countries and, in addition, its presentation seriously understates the decision making process of firms leading to eventual activity in FDI. 
One of the more interesting hypotheses that can be interpreted through the empirically estimated partial adjustment model postulated in Section (III) of this study was developed by Knickerbocker (1973) under the title: 'oligopolistic reactions hypothesis' (5). It was revealed that FDI was bunched together for a sample of 187 American firms with competitive advantage arguments being the cause of such behaviour. This 'oligopolistic reaction' scenario was found to be empirically valid in the field of FDI when increased industrial concentration showed increases in the degree of oligopolistic reaction of competitors.

Empirical work by Flowers (1975) on FDI to the U.S. from Canada and Europe (U.K., France, Federal Republic of Germany and the Netherlands) found a significant positive correlation between the concentration of FDI in the U.S. and reactions encouraging further FDI or concentrations following from these investing countries (6). As will be expanded on in due course, it can be argued that the specification utilized in this paper contains an explanatory variable (one-period lagged FDI stock) that could be interpreted as containing concentration features outlined above. In this framework, it should be observed that the relation between FDI flows and the lagged stock would be positive over time if the stock is not already at its saturated level of concentration. That is, if the sample observed captures the oligopolistic reaction then the relation will show a positive co-efficient (as it shows in this study for Italy and Belgium-Luxembourg). Alternatively, a negative co-efficient should imply either one of a possible two events. Either the 'oligopolistic reactions hypothesis' fails on its own account, or the saturation of FDI has already occurred in a previous period that is not included within the present time frame. Therefore, if the present sample does not include this reaction phase, then the risk of misinterpreting the outcome will be apparent. I will expand on these arguments as well as presenting the results in Section (III) when the individual cases are considered.

The perceived climate of deregulation in the recent past concerning FDI inflows seems to have been based on legal and administrative barriers as well as incentives created through the manipulation of tariff levels and tax rates. On the surface, these revisions could very well be interpreted as deliberate competitive reactions by O.E.C.D. member states that serve to attract new FDI as well as encourage existing commitments to relocate in response to lowering their "permanent" costs.

However, various empirical studies reject the validity of this theory. Most notably, Aharoni (1966) concluded that the initial decision by firms to proceed with FDI is not conditioned by such considerations as income tax exemptions, etc. Moreover, studies conducted by Barlow and Wender (1955), Ross and Christensen (1959) and Robinson (1961) all reject the validity of the incentive theory (7). More recently, studies by the O.E.C.D. continue to confirm previous findings:“...other cost considerations, seen by business as more permanent or more geared to the fundamental soundness of the project, usually seem to prevail... incentives tend to exert a significant influence at a later stage of the decision process, after the basic decisions concerning investment abroad (i.e. the decision to service a particular market or set of markets through establishment rather than through exports) have been taken." (8)

Since the breakdown of the fixed exchange rate system in 1973, it has been observed that fluctuations in exchange rates seldomly adjust to differing inflation rates, as was the case initially advance by those advocating a free floating system. Instead, we have observed an almost continuous misalignment in real bilateral rates that affect the consolidated financial position of all multinational corporations. Consequently, a very recent literature has emerged which investigates 
these effects on the decisions to pursue FDI plans, which treats the impact as affecting the initial considerations taken in the decision - making process.

Specifically, various studies on this issue produce conflicting results that elicit many interpretations of the causes on the propensity to invest. What should be kept in mind is that although this study places particular emphasis on real exchange rate fluctuations, it is not my intention to neglect other possible factors that may be of significance. Ideally, the approach undertaken here attempted to integrate the exchange rate theory with a number of other factors as was referred to from time to time throughout in this section. Although this has statistically eliminated a number of variables that were initially perceived to have been of importance, it has attempted to reinforce a more eclectical approach to the issue of FDI.

Further, it will not be my intention to review all of the different results here, but rather, this paper focuses attention on the most recent approach taken by Cushman (1985), and more or less follows his format with specific additions and extensions included in the theoretical overview in the following section. (9) 


\section{THEORETICAL CONSTRUCTS}

This section develops on the standard theoretical approach that is taken in the trade and FDI literature. Central to this approach is the use of the mean-variance mechanism that enters into the maximization process of an expected utility function. All variables considered are stated in real terms unless otherwise indicated. This approach follows the format established by Cushman (1985) and which departs from previous attempts to model FDI by considering nominal exchange rate variables. The break with the nominal approach is appropriate for consideration of long term investments where departures from purchasing power parity (P.P.P.) have been commonly observed ever since the advent of the free floating system in 1973. The departures from (P.P.P.) represent real exchange rate fluctuations that eventually impact on the real returns from capital assets.

The analysis evolves from the standpoint of profit maximization which yields essentially similar results to net present value maximization. The essential features involve the adjustment of marginal products to their respective real market rates within the host country considered. Such profit maximizing behaviour with respect to the capital stock (planned and existing) within the host country, leads to FDI only if financed through domestic funds. This definition of FDI follows from that used by the U.S. Department of Commerce, and, for greater certainty, also includes the reinvestment of earnings generated in the previous years of operations in the host country.

It is vital to make a distinction between real exchange rate levels, expected real exchange rates and uncertain future changes in real exchange rates. Each will impact the firm's profit function in a different way which will be elaborated on shortly. The derivation which is presented below, follows that which appears in Cushman, however, various revisions and additions will be expressed throughout the formulations. Moreover, I will attempt to integrate a segment of the trade theory with FDI by means of the inclusion of the balance of trade variable which appears significant in a number of the estimated regressions.

Prior to the technical elaborations, I would like to address the two separate issues of financial reporting conventions as well as the hedging of risks in the trade and FDI literature. I would initially submit the proposition that random real exchange rate effects need not necessarily enter into a firm's profit function if legal financial reporting conventions did not require a yearly consolidation of all operations.

For expositional purposes, it can be argued, that operations in a separate jurisdiction with a different unit of account (currency) would not be susceptible to periodic real exchange rate fluctuations affecting FDI. It would follow that such a legal separation between subsidiary and parent company would impinge upon the propensity to invest when real exchange rate fluctuations are considered. If such investments were not subjected to the yearly reporting of their consolidated positions, then the translation of the operations and subsequent repatriation of retained earnings and the liquidated assets would be a once-and-for-all concern coming at the end of the project undertaken. The long time horizon of the project would provide a natural hedge between the initial decision to invest and the eventual liquidation and repatriation of the assets upon termination. In addition, the final translation of the liquidated enterprise may be prolonged if the exchange rate level is not favourable. However, this cannot be done in practice as reviewed above and summarized by Garner and Shapiro: "companies with international operations have foreign currency - 
denominated assets and liabilities, revenues and expenses. But, because home country investors and the entire financial community are interested in home currency values, the foreign currency [B]alance [S]heet and [I]ncome [S]tatement accounts must be assigned home currency values. In particular, the financial statements of an MNC's overseas subsidiaries must be translated into home currency values before consolidation with the parents financial statements". (10)

A firm cannot escape its yearly consolidated reporting obligations, and as such, real rate fluctuations will affect not only the translated financial positions of the subsidiaries at year-end, but also future FDI decisions. Therefore, this is the underlying basis on which the theoretical exposition will be developed throughout sections II.1, II.2 and II.3.

In my judgement, a dual effect exists in consolidating all foreign operations. Firstly, statutory reporting requirements must be met for investors. The actual translation on the surface is artificial since no funds necessarily need to be transferred physically. We will attempt to model the actual re-patriation of profits by the lagged real level exchange rate. For the FDI flows are defined to include not only new initiatives originating from the home country, but also the re-invested and retained earnings from the previous fiscal year's operations. Understandably, my choice of a oneperiod lagged $\mathrm{e}_{t}$ is debatable, however, I would tend to justify this as being reasonable on the basis that information on the financial position of a firm is usually revealed with a lag. Therefore, the decision to re-patriate or re-invest at this moment is a once-and-for-all commitment that is instantaneous. The profit represented by the outcome of period 1 operations can be divided into the portion to be re-patriated and that which is re-invested occurring at the outset of period 2 . This would present $\mathbf{e}_{\boldsymbol{t}}$ - the lagged real level as being determined at the end of the first period referred to above. Operations continue in the second period, however, the firm is assumed to arrive at a decision instantaneously at the beginning of the second period concerning actual re-patriation or re-investment of profits accruing from period 1. 
The following represents a listing of all variables considered throughout the formal developments in II.1. II.2 and II.3 as well as the empirical section III that is to follow:

\begin{tabular}{|c|c|c|}
\hline $\mathrm{Y}_{1}{ }^{*}, \mathrm{Y}_{2}{ }^{*}$ & $=$ & Real foreign revenues in period one and two respectively. \\
\hline $\mathbf{Q}_{2}$ & $=$ & $\begin{array}{l}\text { Real export revenues derived in period two in domestic } \\
\text { currencv. }\end{array}$ \\
\hline$W_{1}{ }^{*}, W_{2}{ }^{*}$ & $=$ & Real foreign wage rate in period one and two respectively. \\
\hline $\mathrm{L}_{1}{ }^{*}, \mathrm{~L}_{2}{ }^{*}$ & $=$ & $\begin{array}{l}\text { Real foreign labour input in period one and two } \\
\text { resnectivelv. }\end{array}$ \\
\hline $\mathbf{R}_{\mathbf{1}}{ }^{*}, \mathbf{R}_{\mathbf{2}}{ }^{*}$ & $=$ & $\begin{array}{l}\text { Real foreign capital cost in period one and two } \\
\text { respectivelv. }\end{array}$ \\
\hline $\mathrm{K}_{1}{ }^{*}, \mathrm{~K}_{2}{ }^{*}$ & $=$ & $\begin{array}{l}\text { Real foreign capital input in period one and two } \\
\text { resbectivelv. }\end{array}$ \\
\hline $\mathbf{d}, \mathbf{d}^{*}$ & $=$ & $\begin{array}{l}\text { Capital depreciation rate in the foreign (and domestic) } \\
\text { jurisdictions respectively. }\end{array}$ \\
\hline $\mathbf{e}_{\boldsymbol{t}}$ & $=$ & $\begin{array}{l}\text { lagged end of period real exchange rate level or terms of } \\
\text { trade. }\end{array}$ \\
\hline \multirow[t]{3}{*}{$\square_{\square}, \square_{\square}$} & $=$ & Parameters representing the proportionate debt \\
\hline & & $\begin{array}{l}\text { obligation repayments relative to the total amounts of FDI } \\
\text { period one and period two respectively. }\end{array}$ \\
\hline & & $\begin{array}{l}\text { Furthermore, and indirectly interpreted as risk exposure } \\
\text { section II.3 }\end{array}$ \\
\hline$\square$ & $=$ & $\square e_{t}$ - the change in the real exchange rate level. \\
\hline $\mathbf{W}_{2}$ & $=$ & Real domestic wage rate in period two. \\
\hline $\mathbf{L}_{2}$ & $=$ & Real domestic labour input in period two. \\
\hline $\mathbf{R}_{\mathbf{2}}$ & $=$ & Real domestic capital cost in period two. \\
\hline$E(u)$ & $=$ & Expected utility operator. \\
\hline $\mathrm{Ee}_{\boldsymbol{t}}$ & $=$ & $\mathbf{e}_{t}$ \\
\hline$E()$. & $=$ & Expectation operator. \\
\hline$\square$ & $=$ & Standard deviation. \\
\hline$\square$ & $=$ & Co-efficient of risk aversion: ( $\square>0=$ ) risk-aversion. \\
\hline$\square()$. & $=$ & Profit function. \\
\hline
\end{tabular}


All of the above variables that contain asterisks represent foreign values. For simplicity in presentation, the change in the real exchange rate level (9), will be rewritten such that it reduces to the random variable $\mathbf{e}_{t+1}$ as follows:

$\square=\square \mathbf{e}_{t}=\mathbf{e}_{t+1} / \mathbf{e}_{t}$

This expression will further reduce to $\mathbf{e}_{t+1}$ if the foreign denominated profit function is multiplied through by the level $\mathbf{e}_{t}$ as well as by the above component $\mathbf{e}_{t+1} / \mathbf{e}_{t}$, representing the real change in the level. This can be presented as follows:

$\square \square \mathbf{e}_{t} \quad=\quad \mathbf{e}_{t+1} / \mathbf{e}_{t} \cdot \mathbf{e}_{t}=\mathbf{e}_{t+1}$

Therefore, $\mathbf{e}_{t+1}$ will be used to capture the random real exposure of foreign operations to relative bilateral exchange rate fluctuations.

Throughout the presentation of the first order maximization processes, the revenue terms $Y_{1}{ }^{*}, Y_{2}{ }^{*}$ and $Q_{2}$ are functions of $L_{1}{ }^{*}, K_{1}{ }^{*}, L_{2}{ }^{*}, K_{2}{ }^{*}, L_{2}$ and $K_{2}$ respectively, such that

$Y_{1}{ }^{*}=f\left(L_{1}{ }^{*}, K_{1}{ }^{*}\right) Y_{2}^{*}=f\left(L_{2}{ }^{*}, K_{2}^{*}\right) Q_{2}=f\left(L_{2}, K_{2}\right)$

Once again, for simplicity, I utilize the short forms $\mathbf{Y}_{1}{ }^{*}, \mathbf{Y}_{2}{ }^{*}, \mathbf{Q}_{2}$ in the profit functions.

The profit function representing operations in the host country includes revenue denominated in foreign currency $\left(\mathbf{Y}^{*}\right)$; the total wage bill $\left(\mathbf{W}^{*} \mathbf{L}^{*}\right)$; cost of capital $\left(\mathbf{R}^{*} \mathbf{K}^{*}\right) ; \quad$ the depreciation cost $\left(\mathbf{d}^{*} \mathbf{R}^{*} \mathbf{K}^{*}\right)$ and the financing expense that is denominated in domestic currency $\left(\mathbf{R} \square \mathbf{K}^{\star}\right)$. Where $\mathbf{0} \square \square \square \mathbf{1}$, which represents the proportion of FDI that is debt financed. In the models presented here, I assume that FDI can occur by either being debt financed only through accessing domestic credit markets or by re-investing the proceeds generated through host country operations in period one. If $\square=1$, then the entire project is financed by credit, whereas $\square=0$ would indicate that FDI shows only an instantaneous stock increase by re-investment of previous earnings. Throughout this paper, I will assume that the FDI pattern follows the empirical evidence, indicating that $\square$ does not incur a comer solution either at 0 or 1 .

Furthermore, the fact that FDI is financed domestically in domestic currency and interest rates, sets an opportunity for the firm to effectively hedge its operation vis-a-vis the currency of the host country. A complete treatment of this idea is presented in section II.3.

The models are all set within a two period framework, as was referred to from time to time above. The firm is presented as having committed itself to FDI at the beginning of period one with the outcome of its operations known at the beginning of the second period. For illustrative purposes, we inspect the FDI decision more closely prior to the commencement of the second period, having already known the outcome of period one operations.

I choose this interpretation as a deliberate attempt to reveal the importance of the translation effects that are applicable to the profits generated in period one. The decision to re-invest or re-patriate at the outset of the second period is determined by the relative level of the exchange rate between the host and home countries. Consequently, it is here that I invoke the lagged level $\mathbf{e}_{t}$ at the end of period one as the appropriate factor that influences the instantaneous FDI decision. I assume a homogeneous decreasing returns to scale production function applicable jointly to both foreign and 
domestic operations, and maximize with respect to $\mathrm{K}^{*}$ *FDI and $\mathrm{L}^{*}$ respectively to obtain the necessary first-order conditions.

Presented over two periods and as viewed at the outset of the second period, the profit function is as follows:

$\square(F D I)=\left[Y_{1}{ }^{*}-W_{1}{ }^{*} L_{1}{ }^{*}-R_{1}{ }^{*} K_{1}{ }^{*}-d^{*} R_{1}{ }^{*} K_{1}{ }^{*}\right] e_{t}-R_{1} \square{ }_{1} K_{1}{ }^{*} e_{t}+\left[Y_{2}{ }^{*}-W_{2}{ }^{*} L_{2}{ }^{*}-R_{2}{ }^{*} K_{2}{ }^{*}-d^{*} R^{*}{ }_{2} K_{2}{ }^{*}\right] e_{t+1}-R_{2} \square{ }_{2} K_{2}{ }^{*} e_{t}$.

Where all asterisks represent denominations in host country currencies or stocks in the host country. The decision to pursue FDI is made at the end of period one and prior to period two. The above function can be substituted in the expected utility function:

$E(u)=E(\square(F D I))-\square \square[\square(F D I)] ;$

where $\square$ is the co-efficient of risk aversion and for risk averse scenarios is assumed to be greater than 0 . For simplicity in substitution, I define the following variables:

$$
\begin{gathered}
X=Y_{1}{ }^{*}-W_{1}{ }^{*} L_{1}{ }^{*}-R_{1}{ }^{*} K_{1}{ }^{*}-d^{*} R_{1}{ }^{*} K_{1}{ }^{*} Y=Y_{2}{ }^{*}-W_{2}{ }^{*} L_{2}{ }^{*}-R_{2}{ }^{*} K_{2}{ }^{*}-d^{*} R_{2}{ }^{*} K_{2}{ }^{*} \\
\square(F D I)=X e_{t}-R_{1} \square{ }_{1} K_{1}{ }^{*} e_{t}+Y e_{t+1}-R \square 2 K_{2} e_{t}
\end{gathered}
$$

we can now substitute this in the expected utility function above:

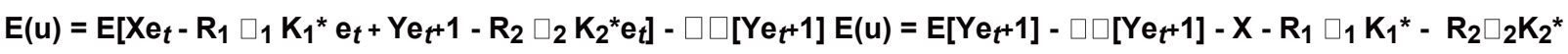

$$
\begin{aligned}
& E(u)=Y e_{t^{+1}}(E-\square \square)-X-R_{1} \square_{1} K_{1}^{*}-R_{2} \square_{2} K_{2}^{*}
\end{aligned}
$$

Where the random variable $\mathrm{Ye}_{t^{+1}}$ is the second period FDI decision that is affected by the expected real exchange rate, as well as the standard deviation. Note that $(X)$ representing period one is impervious to the expectation as well as any deviations since it represents already the period one outcome at the onset of the second period. Consequently, the firm's problem can now be stated in terms of estimating $(\mathrm{E}-\square \mathrm{C})$ that corresponds to $\mathrm{Ye}_{\mathbf{t}^{+1}}$.

The final expression can be interpreted as follows:

(1)

$\mathbf{X}$-represents the profit generated at the end of the first period. As is presented by the mean-variance construct $(\mathrm{E}-[\mathrm{C})$, we see that no variability enters the determination of the FDI decision. Instead, the decision concerning FDI here is discontinuous representing instantaneous actual re-investment or re-patriation, depending on the level of the exchange rate at the end of period one.

$\mathrm{Ye}_{\mathrm{t}} \mathbf{1}(\mathrm{E}-\mathrm{-} \mathrm{C})$ - represents the future FDI commitment in period two. Expectations play an influential role in this case as the firm must estimate the variability of the real rate $e_{t+1}$. As a result, the expected exchange rate $\mathrm{E} \mathrm{e}_{t}$ and the offsetting standard deviation ( $\square$ () are taken into account when deciding on how much to commit for new FDI. I note that unlike the instantaneous FDI choice at the end of period one, the present decision will concern a continuous flow of FDI that will mature and commence produc- tion at the end of period two.

(3) $\quad\left(\mathbf{R}_{\mathbf{1}} \square \mathbf{K}_{\mathbf{1}} *\right)\left(\mathbf{R}_{\mathbf{2}} \square_{\mathbf{2}} \mathbf{K}_{\mathbf{2}} *\right)$ - represents financing expense per annum in home country denominated currency. As will be argued in the third section, and as is mentioned above, this expression can be hedged by contracting into a cross currency swap which is essentially a long term forward contract. 
Therefore, to reiterate and condense the above three considerations; at the start of the second period, the firm makes two decisions that effect FDI. The first is instantaneous and has a past horizon framework (outcome of the operations in period one) represented by (1) above, and the second influences new future commitments during the second period as represented by (2) above.

Since the decision to re-patriate or re-invest the profits occurs at the beginning of the second period and is instantaneous by assumption, then there will exist a discontinuous change in the stock of capital followed by whatever the FDI flow decision will be in the second period decision. The instantaneous effect exerted by the level exchange rate on FDI can be viewed as occurring through an active market for existing capital - stock, either by the outright purchase and transfer of the additional productive capacity, or by accessing the leasing market. Regardless of the form of acquisition, it is assumed that the addition to productive capacity is immediate and separate from the flow commitment that emanates from the FDI decision within period two.

However, the relative effects of these two separate influences are captured in period two. The instantaneous FDI being registered as a sudden rise, or fall, in stock at the beginning of period two, and the flow commitment in period two terminating at the end. Therefore, empirical investigation should reflect both decisions in the second period. It is interesting to evaluate the net effects on FDI as a result of these two factors interacting against one another or in the same direction.

\section{Profit Maximization With Respect To $\mathrm{K}_{2}{ }^{*}, \mathrm{~L}_{2}{ }^{*}$}

I assume stationarity in the factor costs $\left(\mathbf{R}^{*}, \mathbf{W}^{*}\right)$ in the host country for the duration of any single period. Moreover, no firm or group of firms can exert any price effects on host country factor markets through their FDI actions within the sample that is taken into consideration here.

If we consider the argument developed above, where a once and for all investment is carried over from period one to two, then the capital stock in period two $\left(\mathrm{K}_{2}^{*}\right)$ embodies a stock effect at the outset of the second period. However, what the first order condition will capture is the flow of FDI occurring in the second period from new commitments that are financed in domestic credit markets. It will not capture discontinuous once-and-for-all effects from the effects exerted by the exchange rate level on translation of profitable operations from period one.

Therefore, the maximization in period two, representing flow additions to FDI will be independent of the lagged level exchange rate $\mathbf{e}_{t}$ that only exerts a discontinuous once-and-for-all adjustment in the stock of capital $\left(\mathrm{K}_{2}{ }^{*}\right)$. I proceed with the first-order conditions, differentiating the expected utility function above with respect to $\mathrm{K}_{2}{ }^{*}, \mathrm{~L}_{2}{ }^{*}$ :

$$
\begin{array}{lll}
\mathrm{E}(\mathrm{u}) & =\mathrm{Ye}_{t^{+1}}(\mathrm{E}-\square \square)=\mathbf{R}_{2} \square \mathrm{K}_{2} \mathrm{~K}^{*} \\
\square \mathrm{E}(\mathrm{u}) / \square \mathrm{K}_{2}{ }^{*} & =\mathrm{Ye}_{\mathrm{t}^{+1}}\left(\mathrm{~K}_{2^{*}}\right)(\mathrm{E}-\square \square)-\mathrm{R}_{2} \square 2 \\
& & 0 \\
\square \mathrm{E}(\mathrm{u}) / \square \mathrm{K}_{2}{ }^{*} & =\mathrm{Ye}_{t^{+1}}\left(\mathrm{~K}_{2}{ }^{*}\right)=\mathbf{R}_{2} \square 2 /(\mathrm{E}-\square \square)
\end{array}
$$


Likewise, for $\mathbf{L}_{2}{ }^{*}$ the first order condition is:

$\begin{array}{lll}\mathrm{E}(\mathrm{u}) & = & \mathrm{Ye}_{t^{+1}}(\mathrm{E}-\square \square)=\mathrm{R}_{2} \square \mathrm{K}_{2} \mathrm{~K}^{*} \\ \square \mathrm{E}(\mathrm{u}) / \square \mathrm{L}_{2}^{*} & = & \mathrm{Ye}_{t^{+1}}\left(\mathrm{~L}^{*}\right)(\mathrm{E}-\square \square)=0 \\ \square \mathrm{E}(\mathrm{u}) / \square \mathrm{L}_{2}^{*} & = & \mathrm{Ye}_{t^{+1}}\left(\mathrm{~L}^{*}\right)=\mathrm{W}_{2^{*}}\end{array}$

This condition is independent of any exchange rate fluctuations since the wage bill is assumed to be covered by host country revenues and no transfers are specifically earmarked for domestic operations in order to cover such costs. $\mathbf{W}_{2^{*} \mathbf{L}_{2}}{ }^{*}$ is implicitly a part of $\mathrm{Ye}_{t^{+}}$and is not shown for the first order condition with $\left(\mathrm{K}_{2}{ }^{*}\right)$, such that we may maintain a simplistic format.

We follow with an analysis for $\left(\mathrm{K}_{2}{ }^{*}\right)$ only:

$$
\mathrm{E}(\mathrm{u}) \mathrm{K}^{*}: \mathrm{Ye}_{t^{+1}}\left(\mathrm{~K}^{*}\right)
$$

This expression equates the marginal product of FDI to the real cost of capital in the host country implicitly through $\mathbf{Y e}_{t}+\mathbf{1}$ as well as the home country. As the cost of capital $\left(\mathbf{R}_{\mathbf{2}} \square_{\mathbf{2}}\right)$ increases, net disinvestment must occur in order to raise the marginal product and re-establish the equilibrium under profit maximization. It is useful to note the interplay of $(\mathrm{E}-\mathrm{\square} \mathrm{C})$, the term that represents the expected rate of exchange and the variability of that real rate over the course of the second period.

The term (E- $\square$ ) contains the following unique interpretations:

1) $\quad\left(\mathrm{E}-\mathrm{C}_{\mathrm{C}}>\mathbf{1}\right.$ :Foreign currency is expected to appreciate over period two.

2) $(\mathrm{E}-\mathrm{G})=1$ :Foreign currency is expected not to change over period two.

3) $\left(\mathrm{E}-\mathrm{C}_{\mathrm{C}}<1\right.$ 1:Foreign currency is expected to depreciate over period two.

If we apply scenario (1) to the above marginal condition, the interpretation would read as follows:

If the host country real exchange rate rises relative to the home country, then the relative appreciation of host currency lowers the cost of capital from the term $\mathbf{R}_{\mathbf{2}} \square \mathbf{2} /(\mathrm{E}-\square \square)$, thus raising the inflow to the host country of additional FDI. Likewise, an expected depreciation in host country currency will raise the cost of capital leading to a decreasing rate of FDI.

Moreover, it is interesting to note the effect exerted by the co-efficient $\square_{\mathbf{2}}$ representing the proportion of FDI financed through the domestic credit markets. If $\square_{2}$ should be 0 , implying no FDI flows in period two, but only having the once-and-for-all translation impact from period one, then the term $\mathbf{R}_{\mathbf{2}} \square \mathbf{2} /(\mathbf{E}-\square \square)$ shows no impact on the profit-maximizing decision of the firm. It also shows, that any financing decisions at home exert an additional cost to the pursuit of FDI over and above the cost of capital that exists in the host country represented by $\mathbf{R}_{2}{ }^{*}\left(1-\mathbf{d}^{*}\right)$ and included implicitly within $\mathbf{Y e}_{t^{+}} 1$. It is interesting to note how domestic financing and movements in the real expected exchange rates affect FDI flows. For if there is an expected depreciation in the home real exchange rate, then this would raise 
the cost of pursuing additional FDI. This exchange rate effect influences FDI decisions without even having any impact from movements in the domestic rate of interest $\left.\mathbf{( R}_{\mathbf{2}}\right)$.

Further, we can see that domestic financing costs $\left(\mathbf{R}_{\mathbf{2}}\right)$ certainly play a vital role with respect to the flow of FDI. For instance, if we consider an increase in the domestic real rate of interest $\left(\mathbf{R}_{\mathbf{2}}\right)$ then the cost of capital in the host country will rise, inducing a decrease in the rate of growth of FDI to re-establish the profit maximizing parity between the cost of capital and the marginal revenue product. If, however, we encounter such an adverse affect in domestic credit markets, then in order to maintain a stationary rate of flow in FDI, we must have a corresponding offset by an expected appreciation of the host country currency through (E- $\mathrm{E}$ ).

The fact that we have a direct impact on FDI flow from domestic credit market events will allow the firm engaged in such ventures to hedge any expected adverse effects over period two in this model. This will be developed further after due consideration is given to exports as a substitute for FDI.

\section{2}

This section expands on the general development in the previous section above by allowing for the impact of domestic exports as a substitute for FDI flows in period two. The motivation behind the inclusion of this consideration is to contrast the traditional 'portfolio approach' through (E- $\square \square$ ) above. The above general framework shows that an expected appreciation of foreign currency $\mathrm{Ee}_{t}$ lowers the cost of capital, hence increasing FDI. Alternatively, an increase in exchange risk ( $\square$ ) increases the cost of capital, hence lowering FDI. This represents conventional wisdom in portfolio theory, and the purpose of this section is to show how the impact of exports as a substitute for FDI flows may alter the standard result.

I retain the expected utility framework presented above, but amend the profit function such that it also includes export profits from home production as follows:

$$
=\quad\left[Q_{2} e_{t}+1-W_{2} L_{2}-d R_{2} K_{2}-R_{2} \square_{2} K_{2}\right] e_{t}
$$

Once again consideration is given to new FDI flow commitments occurring in period two. It is assumed that $\mathbf{Q}_{\mathbf{2}} \mathbf{e}_{\mathbf{t}^{+1}}$ represents the stochastic effects from real rate fluctuations. Further, in this example, I assume that all invoicing is made in the host country denominations. The other variables $\mathbf{W}_{\mathbf{2}} \mathbf{L}_{\mathbf{2}}, \mathbf{d R}_{\mathbf{2}} \mathrm{K}_{\mathbf{2}}$ and $\mathbf{R}_{\mathbf{2}} \square \mathbf{K}_{\mathbf{2}}$ represent the domestic wage bill, depreciation costs and domestic cost of capital respectively.

Therefore, we can add the profits from exports $-\square(E X)$ with the profits from FDI-( $\square$ (FDI)) and substitute both in the expected utility function. I consider only the FDI effects in period two:

$$
\begin{array}{lll}
\square(\mathrm{FDI}) & = & \mathrm{Ye}_{t+1}-\mathrm{R}_{2} \square{ }_{2} \mathrm{~K}_{2}{ }^{*} \mathrm{e}_{t} \\
\square(\mathrm{EX}) & = & {\left[\mathrm{Q}_{2} \mathrm{e}_{t+1}-\mathrm{W}_{2} \mathrm{~L}_{2}-\mathrm{dR} \mathrm{R}_{2} \mathrm{~K}_{2}-\mathrm{R}_{2}{ }_{2} \mathrm{~K}_{2}\right] \mathrm{e}_{t}} \\
\square(\mathrm{FDI})+\square(\mathrm{EX})= & \mathrm{Ye}_{t+1}+\left(\mathrm{Q}_{2} \mathrm{e}_{t+1}\right) \mathrm{e}_{t}-\mathrm{R}_{2}{ }_{2} \mathrm{~K}_{2}{ }^{*} \mathrm{e}_{t}-\mathrm{W}_{2} \mathrm{~L}_{2} \mathrm{e}_{t}-\mathrm{dR} \mathrm{R}_{2} \mathrm{~K}_{2} \mathrm{e}_{t}-
\end{array}
$$

Therefore, the effects on FDI exerted by $\mathbf{e}_{t}$ - the end of period one real exchange rate level are twofold when home exports can act as substitutes for FDI flows. 
For instance, a high $\mathbf{e}_{t}$ level would induce a greater propensity to re-patriate period one earnings instead of increasing stock instantaneously. However, when considering real $\mathbf{e}_{t}$ in terms of trade form, then a high $e_{t}$ level would induce substitution away from FDI to further export concentration. For that matter, both of these effects as influenced by the real exchange rate level will affect FDI in the same direction with no offsetting influence on real FDI flow. Empirical investigation of $e_{t}$ on FDI will include both of these effects when exports would make up a large portion of trade to the United States. On the other hand, if trade is not large, then $e_{t}$ will be primarily influencing translation effects from period one operations of subsidiaries.

It is interesting to compare the net effects that would result from the first order conditions with $\mathrm{K}_{2}{ }^{*}$ and $\mathbf{K}_{\mathbf{2}}$ above. With the above expression, there exists exchange rate level effects when exports are injected. This $\mathbf{e}_{t}$ effect does not enter the general case since no terms of trade effects enter the period two FDI flow decision. However, the expected term (E- $\square \square)$ does influence both marginal

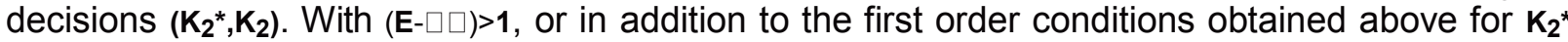
and $\mathbf{L}_{2}{ }^{*}$, the expression FTFDI $+\square(E X)$ is substituted in the expected utility function in order to obtain first order conditions for $K_{2}$ and $L_{2}$.

Once again:

\begin{tabular}{|c|c|c|}
\hline$E(u)$ & $=$ & $E(\square(F D I)+\square(E X))-\square \square(\square(F D I)+\square(E X))$ \\
\hline$E(u)$ & $=$ & $\begin{array}{l}\left.\mathrm{E}\left[\mathrm{Ye}_{t^{+}}+\left(\mathrm{Q}_{2} \mathrm{e}_{t+1}\right) \mathrm{e}_{t}-\square\right] .\left[\mathrm{Ye}_{t^{+1}}+\left(\mathrm{Q}_{2} \mathrm{e}_{t}+1\right) \mathrm{e}_{t}\right]\right]-\mathrm{W}_{2} \mathrm{~L}_{2}-\mathrm{dR} \mathrm{R}_{2} \mathrm{~K}_{2} \\
\quad \mathrm{R}_{2}{ }_{2} \mathrm{~K}_{2}{ }^{*}-\mathrm{R}_{2}{ }_{2} \mathrm{~K}_{2} .\end{array}$ \\
\hline$\square \mathrm{E}(\mathrm{U}) / \square \mathrm{K}_{\mathbf{2}}$ & $=$ & {$\left[Q_{2} e_{t^{+}}\right] K_{2} e_{t}(E-\square \square)-d R_{2}-R_{2} \square 2=0$} \\
\hline$\square \mathrm{E}(\mathbf{U}) / \square \mathbf{K}_{2}$ & $=$ & {$\left[\mathbf{Q}_{2} \mathbf{e}_{t^{+}}+1\right] K_{2}=R_{2}\left(\mathbf{d}+\square{ }_{2}\right) /(E-\square \square)\left(\mathbf{e}_{t}\right)$} \\
\hline
\end{tabular}

Likewise, with respect to $\mathbf{L}_{\mathbf{2}}$ :

$\begin{array}{lll}\square \mathrm{E}(\mathrm{u}) / \square \mathrm{L}_{2} & = & {\left[\mathrm{Q}_{2} \mathrm{e}_{t}+1\right] \mathrm{L}_{2}\left(\mathrm{e}_{t}\right)(\mathrm{E}-\square \square)-\mathrm{W}_{2}=0} \\ \square \mathrm{E}(\mathrm{u}) / \square \mathrm{L}_{2} & = & {\left[\mathrm{Q}_{2} \mathrm{e}_{t+1}+\mathrm{L}_{2}=\mathrm{W}_{2} / \mathrm{e}_{t}(\mathrm{E}-\square \square)\right.}\end{array}$

As was mentioned at the outset, the exchange rate real level affects not only the translation of period one operations, but at the same time, it could have a terms of trade effect on the decision to pursue exports instead of commit itself to further (FDI). An expected appreciation of host country currency will give rise to a greater investment in productive capital at home in order to produce more for the exports that will serve to displace the existing level of FDI flows to the country in question. Likewise, in the first order conditions for $\mathrm{K}_{2}{ }^{*}$, an expected appreciation of foreign currency will induce further FDI inflows to the host country.

Herein lies the impasse that renders the traditional portfolio effect mentioned above uncertain. As an expected appreciation of host country currency will exert opposing influences on FDI flows that need to be judged best empirically. Theoretically, we have met the requirements through developing the first order conditions and discussing the effects in a comparative framework. I leave the resolution of the impasse for the empirical section, and now turn my attention to the presentation of the argument supporting the inclusion of a hedge capability. 


\section{Section II.3}

For the presentation of this section, I will revert to the presentation of the general case in section II.1. The hedge will be applicable to the reduction in the impact of the risky element $\square \square$ in the expected utility function. Once again, I restate the profit-maximizing first-order condition derived on page 12 .

$\square E(U) / \square K_{2}^{*}: Y_{t^{+1}}\left(K_{2}^{*}\right)=R_{2} \square_{2} /(E-\square \square)$

Assuming risk-aversion; $\square \square 0$, a rise in the exchange risk shall increase the cost of capital and adversely affect FDI flows. A simple long-term hedge is applicable in order to contain the risk effect $\square \square$ to manageable proportions.

For instance, if a debenture is issued in domestic credit markets for the expected duration of the FDI project and both the notional amount and the discount rate are denominated in home values, then the risk is to have domestic currency appreciate rendering the commitment at the outset of period two less valuable. If, however, a long term forward contract is purchased at the outset through a cross currency debenture swap, then the interest obligations $\left(\mathbf{R}_{\mathbf{2}} \square_{\mathbf{2}}\right)$ will de denominated in host country currency matched with host country-denominated currency emanating from the FDI project committed with no risk on the translation. If matching of the revenues on the FDI committed should be allocated to meet the home- currency denominated interest obligation $\left(\mathbf{R}_{\mathbf{2}} \square \mathbf{2}\right)$, then currency swings will cause adverse effects. I have assumed throughout that debt-financed obligations denominated in home currency are matched by the revenues emanating from the FDI commitment denominated in host country currency. Such is the nature of the risk that we are confronted with here.

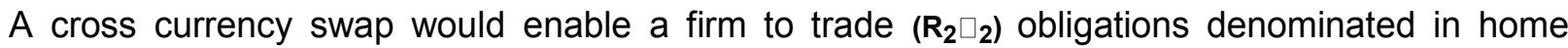
currency for obligations that would be payable in host-country currency or $\left(\mathbf{R}_{\mathbf{2}}{ }^{*} \square_{\mathbf{2}}\right)$. Such a change would alter the nature of the profit function in the second period and further, I would argue that in period two, there would not be a need any longer to maximize expected utility, but just utility. If we replace $\left(\mathbf{R}_{\mathbf{2}} \square \mathbf{2}\right)$ by $\left(\mathbf{R}_{\mathbf{2}}{ }^{*} \square_{\mathbf{2}}\right)$, and restate the profit function as follows:

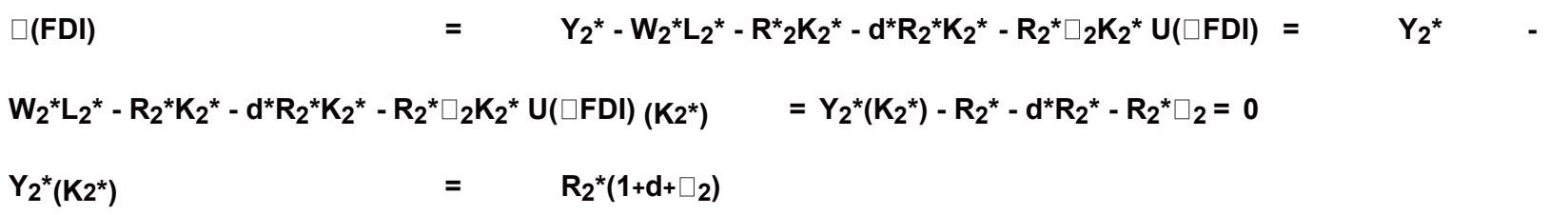

Which is the traditional marginal condition reserved for profit-maximizing output without concern about continuous financing of outstanding home-currency denominated debentures. Moreover, the more that FDI is financed through home denominated debentures $\left(_{2}\right)$, the higher is the effect on $\mathbf{R}_{\mathbf{2}}{ }^{*}$ and the lower will be FDI. This effect occurs indirectly since if home denominated debentures increase rapidly ( $\square_{2}$ rises), the risk is that market-makers will be unable to find the appropriate suitors in host country currency to enable an effective hedge to be established. In such a case, we would be faced with a lop-sided market that would potentially run the risk of having the firm meet its periodic obligations in home currency and run the risk of real rate fluctuations. Therefore, a high $\left(\square_{2}\right)$ acts as an addition to the host real market rate $\left(\mathbf{R}_{2}{ }^{*}\right)$, which has a negative impact on FDI flows. 
What should be kept in mind, however, is that the end of first period translation effects will not be hedged in this model due to riming as well as magnitude problems concerning the actual profit results at period end. Therefore, the hedge here is exclusively limited to home currency finance coverage in the long term forward or cross currency swap market.

Furthermore, I attempt to integrate a segment of trade theory to the above construction, treating $(\square 2)$ - the proportion of FDI flows financed by domestic debt as a premium that conceivably also contains effects exerted by a country's net currency position as reflected through the trade-balance. The thinness of the long term forward market cited above is an outcome that can be potentially aided in the home country by the actions of the central bank. For instance, if the market thinness problem should persist, then a positive trade position generally, or a net positive trade position visa-vis the FDI recipient directly may alleviate the thinness problem. Therefore, if a risk premium is indirectly presented through $\left(\square_{2}\right)$, considered above in the full-hedge case, then, it would most likely in this model be due to market thinness that would deter the optimal FDI flow.

This idea of market thinness entering as a risk premium, as well as the potential reduction of the premium by a positive balance of trade is concisely summarized by De Vries: "the forward rate is equal to the expected spot rate minus a factor, positive or negative, that explains the required normal backwardation. This latter factor constitutes the risk premium.

...It is a function of the thinness of the market, the expected net currency position of the country, the attitudes towards risk and the spot rate volatility. ... Thus the overall trade balance determines whether the risk premium $\left(\square_{2}\right)$ is positive or negative." (11)

Since thinness of the market composes the risk premium within this context, a larger $\left(\square_{2}\right)$ indicates a large volume of debt-financed FDI denominated in home currency. Consequently, the larger the $\left(\square_{2}\right)$ gets, the larger is the risk premium of encountering the problem of market thinness. This all assumes that the firm will engage in long-term forward coverage on it's FDI ventures.

This argument set forth above invokes trade theory and specifically addresses the thinness problem by drawing a connection with the country's net currency position (trade-balance). It is argued that a positive trade-balance will erode the risk premium encountered above, which is represented through market thinness. A positive trade-balance should serve to reduce the proportion of FDI financed domestically and not matched in the forward market. This would have a downward effect on $\left(_{2}\right)$ the proportion uncovered and outstanding in home currency, which would stimulate FDI through the first order condition:

$\mathrm{Y}_{2^{*}}\left(\mathrm{~K}^{*}\right)$

Therefore, empirical investigation of the effects of the trade balance on FDI flows should be positive. If negative effects should result, then either the trade-balance was negative, which would aggravate the thinness problem and further act as a deterrence to FDI flows. Or, if no long term matching hedge could be arranged, as a result of short-durations to financial maturities reflected in the capital-market flows that compose the trade-balance position.

This then concludes the development of the theoretical construct which will serve as a framework for the upcoming empirical investigations. 


\section{Section III - EMPIRICAL ESTIMATES}

In this section, the estimated regressions are presented initially with each country considered separately. It continues with the elaboration of statistical features as well as unique features concerning the country-specific results deserving further attention. In addition, the summary represents a brief comparison of the preceding country-specific results.

The data are annual, spanning the period 1973-1987 and conceptually represent the free floating rate period. The study is conducted in context with the statistical data that was available representing bilateral flows and relationships from the country of origin destined to the United States. Specific consideration is given to a sample of six European countries which for greater certainty include: Belgium-Luxembourg, France, Italy, Germany, the Netherlands and the U.K.

In order to capture imperfect adjustment on behalf of the firms, I follow Cushman and adopt the partial adjustment model:
$\mathrm{FDI}(\mathrm{t}) \quad=$
$\square\left(K^{*}(\mathrm{dt})-\mathrm{K}^{*}(\mathrm{t}-1)\right)$

Where FDI(t) represents this year's investment flow; $K^{*}(d t)$ being this year's desired stock of FDI, $K^{*}(t-1)$ is last year's actual FDI stock and $\square$ is the adjustment co-efficient. For empirical estimation purposes, the above can be re-written in the following format:

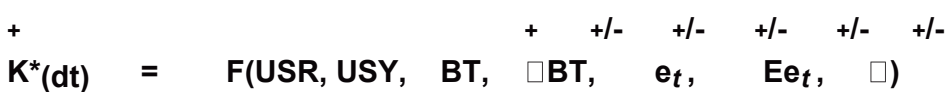

Where, FDI(t) $\quad=\quad \square\left(K^{*}(\mathrm{dt})-\mathrm{K}^{*}(\mathrm{t}-1)\right)$; where $0 \square \square \square 1$.

By sustitution of $\mathbf{K}^{*}(\mathrm{dt})$ above, we obtain the final estimatable equation:

$\left.\mathrm{FDI}(\mathrm{t})=\quad=\quad \mathrm{a}_{0}-\mathrm{a}_{1} \mathrm{~K}^{*}(\mathrm{t}-1)\right)+\mathrm{a}_{2} \mathrm{USR}+\mathrm{a}_{3} \mathrm{BT}+\mathrm{a}_{4} \square \mathrm{BT}+\mathrm{a}_{5} \mathrm{USY}+\mathrm{a}_{6} \mathrm{e}_{t}+\mathrm{a}_{7} \mathrm{Ee}_{t}+\mathrm{a}_{8} \square+\mu$

$\mu=$ stochastic error term.

Unlike Cushman, the data was not pooled, rather (O.L.S.) and $A R(1)$ estimations were performed separately for each individual country. The construction of the variables proceeded as follows:

FDI(t): $\quad$ The dependent variable represents first differences of the logs of the previous periodending capital stock. Therefore, this represents the proportional change in actual real FDI assets from the previous year. The capital stock presented was deflated and is based in 1980 values $(1980=100)$.

$K^{*}(t-1)$ : $\quad$ End of period real capital stock. The above FDI(t) construction was re-combined.

USR: $\quad$ Represents real long-term U.S. interest rates expressed in decimal form. BT:

Represents the log of the yearly trade-balance. 
$\square$ BT:

Represents the percentage change in the yearly trade-balance. USY:

Represents the log of the U.S. gross domestic product.

$\mathbf{e}_{\boldsymbol{t}}$ :

Represents the log of last periods year-end real bilateral exchange rate level.

Hence, this enters the model as a lagged term.

$\mathrm{Ee}_{t}$ :

Represents this periods log of the real mean bilateral exchange rate. Deflated in real terms with the base period $(1980=100)$.

$\square: \quad$ Is an instrumental variable that represents the standard deviation for the year. It was calculated by taking each month end nominal bilateral level and calculating the nominal standard deviation for the year.

Appendix I presents a survey of six chosen regressions for each country considered. Column (1) compares results for a regression which emphasizes the inclusion of the instrumental variable S.D., that represents the standard deviation.

Columns (1) to (3) are results under the standard (O.L.S.) assumptions and columns (4) to (6) represent the $A R(1)$ process (which is preferred to other methods since it saves on degrees of freedom) that attempts to correct for auto-correlation. I emphasize that the AR(1) procedure was also used as a check against the Durbin-Watson indicating an indeterminate outcome. On many occasions such a check confirmed the presence of significant auto- correlation effects.

Further, a quick check across the regressions indicates differing co-efficients when additional variables were inserted or others dropped. This is an indication that multi- collinearity exists, although, it is of a mild degree since most co-efficients are relatively stable and definitely retain their sign. My intention is to present each country individually and briefly elaborate on the empirical results by isolating two of the best equations from the viewpoint of robust statistical indicators. The benchmark for the degree of significance is stated at the $90 \%$ level.

\section{Belgium-Luxembourg}

I chose to present two estimations by the $A R(1)$ procedure, where the second equation does not include the standard deviation term $\square$. This is primarily done in order to suppress multi-collinearity effects.

(1) FDI

$=-11.1+0.62 \mathrm{~K}^{*}(\mathrm{t}-\mathrm{I})+$

2.24USY $-2.3 e_{t}-$

$2.34 \mathrm{Ee}_{t}+$

$1.3 \square(-2.7)$

$\begin{array}{lll}-2 & & \\ \text { R } & & 0.39 \\ \text { D.W. } & = & 2.7 \\ \text { F }(5,8) & = & 2.7 \\ & = & -0.69\end{array}$

\section{$(2.5)(-1.5) \quad(-1.3) \quad(1.5)$}

$=\quad-0.69$

\section{$[1.03] \quad[-1.69] \quad[-2.1] \quad[0.96]$}


Where the $\mathbf{R}^{\mathbf{2}}$ is the adjusted $\mathbf{R}^{\mathbf{2}}$ and all values in round brackets are t-statistics throughout.

Furthermore, the square-bracketed terms immediately below the t-statistics represent beta coefficients whose role is to compare the relative effects exerted on FDI by all of the variables composing the equations. After a brief discussion, I present the values in a table at the end of each separate country considered.

\begin{tabular}{|c|c|c|c|c|c|c|}
\hline $\begin{array}{l}\text { (2) FDI } \\
(-2.3) \\
{[0.18]}\end{array}$ & $=$ & -0.53 & $\begin{array}{l}0.31 \mathrm{~K}^{*}(\mathrm{t}-1)^{+} \\
(1.9)\end{array}$ & $\begin{array}{l}\text { 31.4USR } \\
(2.8) \\
{[2.53]}\end{array}$ & $\begin{aligned}- & 3.8 \mathrm{e}_{t} \\
& (-2.1) \\
& {[-2.04] }\end{aligned}$ & $\begin{array}{l}\quad 0.75 \mathrm{Ee}_{t} \\
(-0.7) \\
{[-1.18]}\end{array}$ \\
\hline $\begin{array}{l}-2 \\
\mathrm{R}\end{array}$ & $=$ & 0.4 & & & & \\
\hline D.W. & $=$ & 2.4 & & & & \\
\hline$F(4,9)$ & $=$ & 3.1 & & & & \\
\hline
\end{tabular}

Both (1) and (2) indicate that the stock of FDI in place exerts a positive effect on present FDI decisions. This is inconsistent to what the partial adjustment model indicates as the appropriate sign of the coefficient. The long term real U.S. rate (USR) exerts a strong positive effect on FDI. Since FDI is defined to be financed domestically, then an increase in the cost of capital in the U.S. will lead to home-financed investment.

Alternatively, there exists a negative impact on the re-investment of foreign profits as the U.S. real interest rate increases by definition. The opportunity cost of re-investing profits in productive capital assets would be the rate of return foregone on paper assets yielding (USR). The interesting interplay between this effect and re-invested profits has also the level of the real exchange rate as an explicit impact variable to consider. This was developed in the theoretical section, as it could be argued that a positive impact of the $e_{t}$ level will offset the effect exerted by (USR) that would deter the act to re-invest profits in productive capital.

However, both equations indicate that the real exchange rate level $\mathbf{e}_{t}$ results in the re-patriation of profits upon the translation of currencies. Thus, I would be inclined to hold the view that the positive FDI impact by USR is a result of domestic financing that takes advantage of the difference in the real rate spread between the two countries. The impact of $\mathrm{Ee}_{t}$ is significant and negative in (1).

This confirms the substitution of FDI for exports. As $E_{t}$ increases, or when the franc depreciates vis-a-vis the U.S. dollar. Furthermore, and unlike the other regressions considered, the (USY) gross domestic product that measures the size of the U.S. market is significant in equation (1). And the proxy for expected exchange rate effects - $\square$, shows a positive effect due to hedging activity according to the theory as developed in section (II.3).

It is interesting to compare the relative effects of (1) on FDI. This can be done by considering beta coefficients where the slope parameters are adjusted by the ratio of the standard deviation of the independent variable to the standard deviation of the dependent variable. The net effect in the Belgian case using (1) shows a negative impact of magnitude (-1.47). This aggregate co-efficient indicates that a net change of positive one standard deviation units leads to a 1.47 standard deviation decrease in FDI. The dominating effect in the equation is generated by the three variables representing real exchange-rate effects $\mathbf{e}_{t}, \mathrm{Ee}_{t}$ and $\square$ The following table shows the relative effects 
of the beta co-efficients for the two regressions:

\begin{tabular}{clllllll} 
& \multicolumn{1}{c}{ USY } & $\mathrm{e}_{t}$ & $\mathrm{Ee}_{t}$ & $\square$ & USR & Totals \\
\cline { 2 - 7 } & \multicolumn{1}{c}{$\begin{array}{c}\text { Regression } \\
(1)\end{array}$} & 0.331 .03 & -1.69 & -2.1 & 0.96 & - & -1.47 \\
$(2)$ & $0.18-$ & -2.04 & -1.18 & - & 2.53 & -0.51 \\
\hline
\end{tabular}


Italy

Also, for the case of Italy, both equations represent $A R(1)$ procedures and are as follows:

(1) FDI $=13.1+$

$0.38 \mathrm{~K}^{*}(\mathrm{t}-1)-3 . \mathrm{OUSY}+31.8 \mathrm{USR}$

$0.14 \square(2.3)$

(2.55)(-2.3)

[0.16]

[-1.4]

(2.7)

$1.05 \mathrm{e}_{t}-$

$5.5 \mathrm{Ee}_{t}+$

$[12.65] \quad[-1.95] \quad[-3.1]$

(0.82)

[0.18]

$\begin{array}{lll}-2 & \\ \text { R } & = & 0.80 \\ \text { D.W. }= & & 3.4 \\ F(6,9)= & & 9.8 \\ \square & \square & -0.97\end{array}$

$(-19.7)$

\begin{tabular}{|c|c|c|c|c|c|c|}
\hline (2) FDI & $=$ & $-0.33+$ & $0.45 K^{*}(t-1)$ & & 0.00005BT- & $4.1 \mathrm{e}_{t}+$ \\
\hline $0.67 \mathrm{Ee}_{t}$ & + & $0.25 \square(-1.02)$ & (3.53) & (2.9) & $(-1.9)$ & $(0.41)$ \\
\hline [0.14] & & & {$[0.0]$} & {$[-2.36]$} & {$[1.74]$} & [0.15] \\
\hline $\begin{array}{l}-2 \\
R\end{array}$ & $=0.82$ & & & & & \\
\hline D.W. = & 3.1 & & & & & \\
\hline$F(5,8)=$ & 13.0 & & & & & \\
\hline 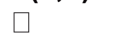 & -0.94 & & & & & \\
\hline
\end{tabular}

Once again, the Italian case goes against the theory and shows significant positive effects with respect to the lagged capital stock influence on FDI. The only significant effect on the exchange rate variables is $\mathrm{Ee}_{t}$ in (1) and all except $\mathrm{Ee}_{t}$ in (2). The rho-corrected error is not very different from 1.

The impact of USY in this case is significant and contradicts the market-size argument by producing a negative co-efficient. The only logical argument would be if FDI was already saturated from the standpoint of capturing marginal market-share rents. Or, the impact could be tied in with the trade-balance term presented in (2), which indicates a very slight effect when inspecting the co-efficient. It could be that a higher U.S. G.D.P. exerts more demand for exports from Italy allowing a positive effect on the trade balance which captures the stimulus in FDI by providing more opportunities to hedge.

Since the two equations present mixed results with respect to the co-efficients on $\mathrm{Ee}_{t}$ and differing t-statistics on $e_{t}$ and $\square$, I will use (2) to determine the relative effects by invoking the beta co-efficient test. Further, it would be interesting to capture the balance-of-trade effect which is significant and will exclude the effect of $\mathrm{Ee}_{t}$ since the t-statistic is not significant. The calculated net effect is $(-0.33)$, which clearly has a depressing effect on FDI. The variable $\mathbf{e}_{t}$ - level exchange rate accounts for most of the effect exerted on FDI flow, and it is shown that the relative effect of the stock of FDI last period is negligible once it is placed within a comparative framework. 
The following table shows the relative effects of the beta-co-efficients for the two regressions:

\begin{tabular}{lcccccccc}
\hline & $\mathrm{K}^{*}(\mathrm{t}-1)$ & USY & USR & $\mathrm{e}_{t}$ & $\mathrm{Ee}_{t}$ & $\square$ & $\mathrm{BT}$ & Totals \\
\hline Regressio & & & & & & & & \\
$\mathrm{n}$ & 0.16 & -1.41 & 12.65 & -1.95 & -3.1 & 0.18 & - & 6.53 \\
$(2)$ & 0.14 & - & - & -2.36 & 1.74 & 0.15 & 0.0 & -0.33 \\
\hline
\end{tabular}




\section{Germany}

For the German case, the results of the empirical work did not show statistically sound results. I present here two of the best equations which are also estimated by (O.L.S.), as well as the $A R(1)$ mechanism to correct for serial-correlation. They are:
(1) $\mathrm{FDI} \quad=\quad 1.4-$
$4.9 \mathrm{Ee}_{t+}$
$0.46 \mathrm{~K}^{*}(\mathrm{t}-1)+17.6 \mathrm{USR}$ -
$0.00003 \mathrm{BT}+1.75 \mathrm{e}_{t}$
2.2)
(0.5)
$0.17 \square(1.42)$
$(-1.43)$
(2.7) $\quad(-1.89) \quad(0.97) \quad(-$
$[-0.84]$
[16.9]
$[0.0]$
[4.7]
$[-5.8]$
[0.95]

$\begin{array}{ll}-2 & = \\ \text { R } & 0.17 \\ \text { D.W. }= & 2.8 \\ F(6,7)= & 1.44\end{array}$
(2) FDI
(2.0)
[-0.52]

$\begin{array}{lll}-2 & = & 0.53 \\ \text { R } & & 2.8 \\ \text { D.W. }= & & 3.5 \\ F(6,7)= & = & -0.65\end{array}$
$=1.3-0.23 \mathrm{~K}^{*}(\mathrm{t}-1)+14.7 \mathrm{USR}-$ $+0.083 \square$
$(-1.1)$
$\begin{array}{ll}(3.7) & (-3.3) \\ {[9.9]} & {[0.0}\end{array}$
$0.00003 B T$
(2.2) $\quad(-3.9)$
[3.3] [-3.6]
$+2.8 \mathrm{e}_{t}-$
$5.5 \mathrm{Ee}_{t}$
[0.66]
$(-2.6)$

In the German case, we see that the negative impact of last period's FDI stock exerts an adverse effect on present FDI decisions. The balance of trade term is significant in both cases but remains to be negligible by the co-efficient. Moreover, various estimated variables such as USY were not included due to statistical insignificance. The $A R(1)$ procedure seems to have firmed-up the exchange rate variables while retaining the original signs derived from the co-efficients in (1). We see that the level rate exerts a positive reinvestment of proceeds generated in the previous year. As well, there is strong signs that exports are substituting for FDI by the negative $\mathrm{Ee}_{\boldsymbol{t}}$ effect. The $\square$ does not show significant results for this case.

For comparative purposes, the beta co-efficients were calculated for both (1) and (2) with values of 15.9 and 9.74 respectively. Once again, there was a dominant effect exerted through the USR variable which effectively offset the negative impact from $\mathbf{E e}_{\boldsymbol{t}}$.

The following table shows the relative effects of the beta co-efficients for the two regressions:

\begin{tabular}{cccccccc}
\hline & $\mathrm{K}^{*}(\mathrm{t}-1)$ & USR & $\mathrm{BT}$ & $\mathrm{e}_{t}$ & $\mathrm{Ee}_{t}$ & $\square$ & Totals \\
\hline $\begin{array}{cccccc}\text { Regression } \\
\text { (1) }\end{array}$ & & & & & & & \\
$(2)$ & -0.84 & 16.9 & 0.0 & 4.7 & -5.81 & 0.95 & 15.9 \\
& -0.52 & 9.9 & 0.0 & 3.3 & -3.6 & 0.66 & 9.74 \\
\hline
\end{tabular}




\section{The Netherlands}

Once again, I select two regressions with the same variables here since the $A R(1)$ transformation was the most beneficial for the Netherlands in terms of producing significant co-efficients. They are presented now:

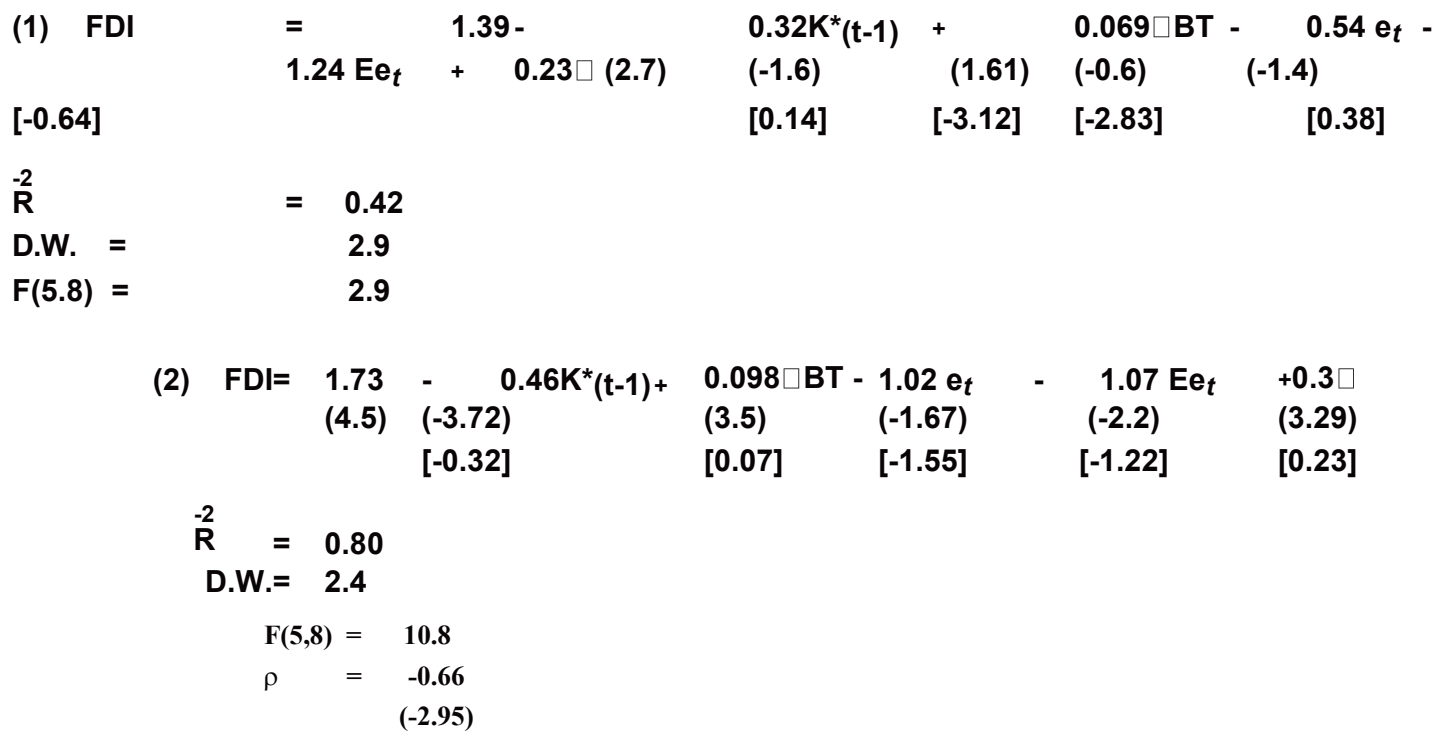

The $A R(1)$ procedure in this case produced significant differences in the t-values without doing harm to the direction of the co-efficients. Since (2) is definitely an improvement, I shall focus my attention on it throughout this section. The lagged capital stock is shown to exert a negative impact on the present decision which is according to theory. The exchange rate variables capture negative effects on the level $e_{t}$ which suggests repatriation of profits from foreign operations, and the mean rate $\mathrm{Ee}_{t}$ shows that exports are substitutes for a depreciating currency and it shows that the expected rate $-\square$ is successfully hedged such that no adverse effects on FDI exist due to uncertainty.

The only difference in this case is the use of a slightly revised variable for the balance of trade, where instead of using the log of the yearly levels, I use the yearly percentage change. This produces a more robust statistical outcome, however, the impact of both BT and $\square$ BT have similar effects on FDI. Hence, I retain $\square \mathrm{BT}$ here.

Utilizing (2) above, the relative effect of the beta co-efficients is $(-2.79)$, where the dominating negative impact emanates from the $\mathbf{e}_{t}$ and $\mathrm{Ee}_{t}$ variables.

The following table shows the relative effects of the beta co-efficients for the two regressions:

\begin{tabular}{ccccccc}
\hline & $\mathrm{K}^{*}(\mathrm{t}-1)$ & $\square \mathrm{BT}$ & $\mathrm{e}_{t}$ & $\mathrm{Ee}_{t}$ & $\square$ & Totals \\
\hline $\begin{array}{c}\text { Regression } \\
\text { (1) }\end{array}$ & & & & & & \\
$(2)$ & -0.64 & 0.14 & -3.12 & -2.83 & 0.38 & -6.07 \\
& -0.32 & 0.07 & -1.55 & -1.22 & 0.23 & -2.79 \\
\hline
\end{tabular}




\section{France}

For France, I will present two equations estimated by $A R(1)$ which show very robust statistical results. The fist includes only the balance of trade term which is in percentage change form, along with the inclusion of the USR. The second includes the balance of trade in log of levels formation:

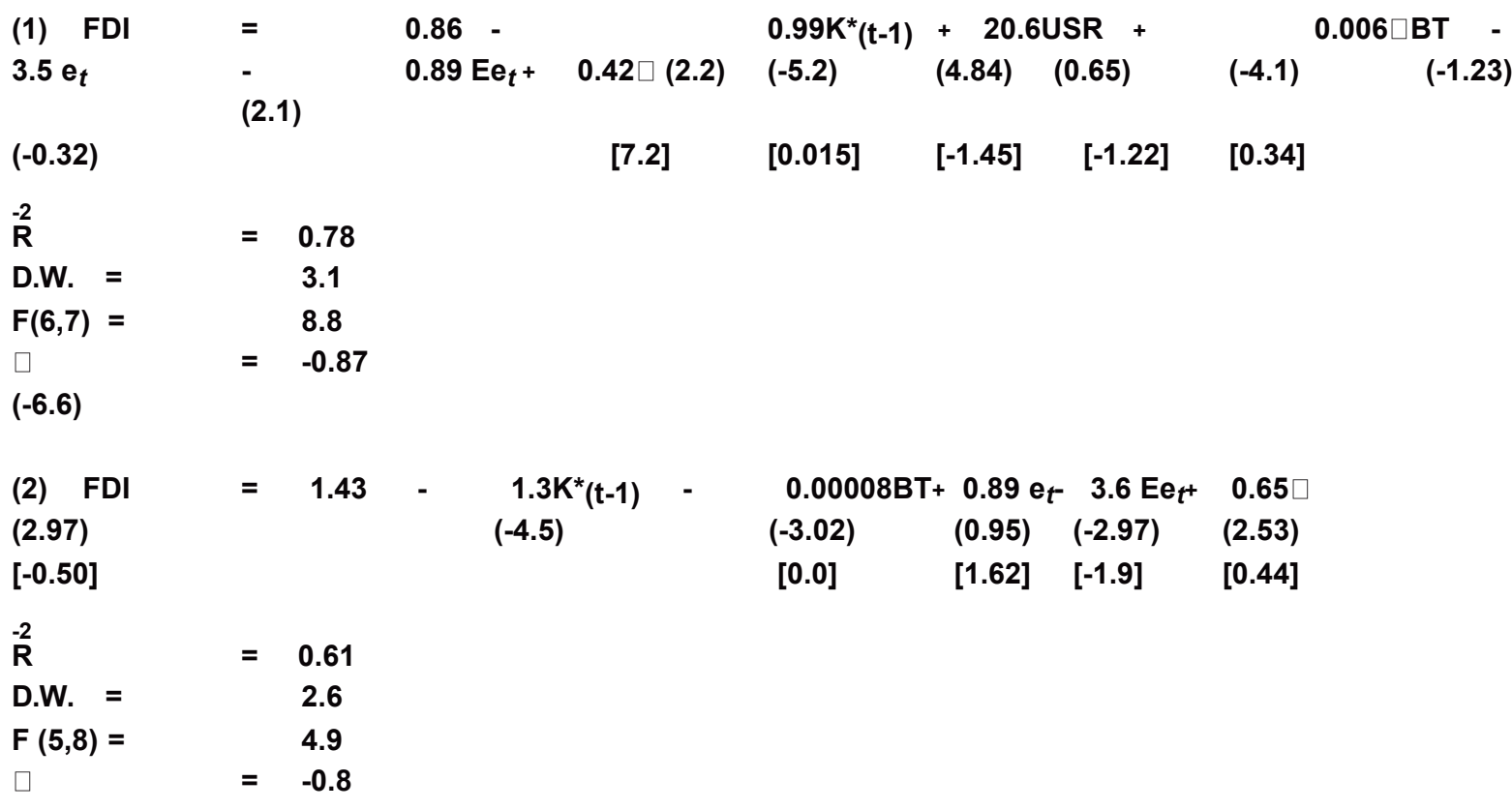

For the two equations presented above, most of the variables with the exception of $\square \mathrm{BT}$ in (1) and $e_{t}$ in (2) are significant. Furthermore, we see the last period's FDI stock exerts very severe negative effects relative to the previous cases considered. The balance of trade has opposite sign effects, however, the negative effect in (2) is what is significant.

We see that as the balance of trade runs into a surplus position, there is a negative impact on FDI. This could have been the result of exchange controls that were implemented in the early 1980's. These controls on the demand for foreign currency from the Central Authorities' accumulated reserves would not be met. This would divert the firm's attention from arranging the transaction domestically, to seeking financing offshore or within the U.S. A check with respect to the beta co-efficients shall indicate the relative impact of the USR variable. It may be the case that a rising long-run real rate of interest would capture the diversion in financing brought about by domestic capital controls. If this should be the case, then the flow of funds into the U.S. credit markets will not be induced by the real spread.

Hence, the real interest rate within the U.S. acts on FDI in a dual format. Firstly, by the affect on domestic financing consistent with the traditional definition of FDI, and secondly, by having no natural effect as in the case here where legislated controls artificially divert borrowing demands to finance FDI within the U.S. domestic credit markets.

Moreover, the scenario may affect the decision to re-patriate profits as is indicated by the positive (although statistically insignificant) impact of the level exchange rate on FDI. The expected change 
in the real rate $\square$ is shown to be positive and exports are indicated as exerting substitutability effects by $\mathrm{Ee}_{t}$. The relative effects of the beta co-efficients from (2) indicate a value of $(-0.34)$ overall on FDI, with the dominating effect being exerted by the yearly mean $\mathrm{Ee}_{t}$ or the substitution of FDI for exports. The following table shows the relative effects of the beta co-efficients for the two regressions:

\begin{tabular}{|c|c|c|c|c|c|c|}
\hline & $K^{*}(t-1)$ & USR $\square \mathrm{BT}$ & $e_{t}$ & $\mathrm{Ee}_{t}$ & $\square$ & Totals \\
\hline \multicolumn{7}{|c|}{ Regression } \\
\hline $\begin{array}{l}(1) \\
(2)\end{array}$ & $\begin{array}{l}-0.32 \\
-0.50\end{array}$ & $\begin{array}{rr} & 7.20 .015 \\
-\quad & 0.0\end{array}$ & & $\begin{array}{l}5-1.22 \\
2-1.9\end{array}$ & $\begin{array}{l}0.34 \\
0.44\end{array}$ & $\begin{array}{r}4.57 \\
-0.34\end{array}$ \\
\hline
\end{tabular}




\section{United Kingdom}

I consider a regression without $\square$ by (O.L.S.), which consistently seems to derive the best statistical results for the U.K. case. Further, I will consider an additional case that includes the percentage change for the balance of trade variable also under (O.L.S.):
(1) FDI
$=0.56-$
$3.5 \mathrm{Ee}_{t}(3.9)$
$(-3.5)$
$0.38 \mathrm{~K}^{*}(\mathrm{t}-1)+$
(3.4) (2.2)
9.1USR +
[8.54]
[2.1]
$(-4.1)$
[-2.75]
$1.5 \mathrm{e}_{t}-$
$[-0.35]$

$\begin{array}{ll}-2 & =0.6 \\ \text { D.W. }= & 2.7 \\ F(4,9)= & 5.7\end{array}$
(2) FDI

$$
=-3.2 \mathrm{Ee}_{t}+
$$
$0.66-0.41 \mathrm{~K}^{*}(\mathrm{t}-1)+9.5 \mathrm{USR}$
$0.02 \square(2.3)(-2.9)$
$[-0.45]$
$\begin{array}{lc}-2 & = \\ \text { R } & 0.52 \\ \text { D.W. }= & 2.6 \\ F(6,7)= & (3.4)\end{array}$
[12.2]
[0.0]
$0.000009 \square \mathrm{BT}+$
(2.3) $\quad(-0.8)$
[2.8] [-3.3]
$\begin{array}{lll}(1.2) & (-3.2) \quad(0.4)\end{array}$
[0.22]

It is interesting to note that in the U.K. case, there does not exist any significant rho-values generated by the $A R(1)$ procedure. The two cases presented here exclusively apply the (O.L.S.) procedure. The results presented indicate all of the standard expected outcomes for $\mathbf{K}^{\star}(\mathrm{t}-1)$, USR, $\mathbf{e}_{t}$ and $\mathrm{Ee}_{t} . \mathrm{In}(2)$, the percentage change in the balance of trade and the expected change in the exchange rate variable S.D. are both insignificant.

Consequently, the beta co-efficient as calculated for (1) stands at 7.54 which indicates that the real exchange rate effects are relatively insignificant as compared to the USR effect. The large relative impact of USR indicates that financing differences between funds accessed domesti- cally and within the U.S. play a major role in the decision to peruse FDI opportunities.

The following table shows the relative effects of the beta co-efficients for the two regressions:

\begin{tabular}{cccccccr}
\hline & $\mathrm{K}^{*}(\mathrm{t}-1)$ & $\mathrm{USR}$ & $\mathrm{e}_{t}$ & $\mathrm{Ee}_{t}$ & $\square$ & $\square \mathrm{BT}$ & Totals \\
\hline Regression & & & & & & & \\
$(1)$ & -0.35 & 8.54 & 2.1 & -2.75 & - & - & 7.54 \\
$(2)$ & -0.45 & 12.2 & 2.8 & -3.3 & 0.22 & 0.0 & 11.47 \\
\hline
\end{tabular}




\section{Summary}

On a comparative basis, the six countries considered above definitely indicate adverse real exchange rate effects when placed in context with the other variables. Not only are they the dominant effect on FDI relative to the alternative variables considered explicitly here, but also all other variables that were sequentially considered and eliminated on statistical grounds and that are left out of the FDI function.

Inspection of the beta co-efficients indicates that definite net negative effects are exerted by the three real exchange rate arguments $\mathbf{e}_{\boldsymbol{t}}, \mathrm{Ee}_{\boldsymbol{t}}$ and $\square$ when considered together. These are the dominant variables for Belgium-Luxembourg, Italy, Netherlands and France that adversely affect FDI. However, it is shown that for Germany and the U.K.; long-term real financing decisions reflected through USR, the real long-term spread over domestic financing supersedes the negative real exchange rate effects. The spread indicated by USR positively affects FDI decisions.

\section{CONCLUSION}

Over the past decade, the position of the U.S. as a net originator of FDI has altered on a relative basis when considered in a comparative context with other O.E.C.D. countries. In fact, the U.S. has become the leading host country for foreign investment, in recent years attracting on occasion more than 50 percent of total international investment flows.(12) This is also captured by evidence that most of the recent FDI flows that originated from the U.S. were in the form of re-invested earnings, whereas a higher proportion of the less mature FDI flows originating from Western European countries were in the form of loans and equity participations with re-invested earnings being the next most important component composing FDI flows.

Although data concerning FDI inflows to the U.S. indicate large levels of increase over the 1980's, the present study attempts to account for the real changes in FDI and is not concerned with nominal levels. Even though it is revealed that real FDI flows have increased to the U.S. from the sample of six O.E.C.D. countries considered here, nevertheless, empirical evidence isolates the significant factors that have prevented a fully optimal position to be realized.

Given that the present position taken by the majority of the O.E.C.D. member-states encourages increasing FDI activity as producing overall positive welfare effects. Then it could be argued that any factors which may present an obstacle to this goal should be addressed.

Empirical evidence in this study indicates that overall net negative effects are exerted by real exchange rate fluctuations on decisions emanating from Belgium-Luxembourg, Italy, Netherlands and France. However, the two most economically and politically influential European countries (Germany, U.K.) indicate that they are impervious to any such variations in the real rate. Based on the evidence in this study, it would be difficult for these two countries to support the fixing of real exchange rates when considering FDI flows separately, since they are positively offset by other factors affecting FDI such as the spread in domestic and foreign financing options.

Although this study would urge those four countries affected to support the fixing of real rates, it would not advocate a similar course of action for Germany and the U.K. Therefore, since unanimity is not present on this issue, and since two of the most important members are not averse to the 
fluctuations, then the most likely outcome would be a regime of continued free floating rates vis-avis the U.S. dollar.

The evidence during this period of pre-globalisation and the impact on FDI flows among G7 member states is interesting in its empirical support of exchange rate uncertainty as the prime cause in the causal effect that it would have on the optimal FDI cross-border flow. The evidence here using the OLS technique and the data provided by the U.S. Dept. of Commerce supports this pre-globalisation paradigm. A forthcoming sequel to this paper investigating FDI flows in the era of globalisation from 1990 to 2016 will empirically investigate whether wage rate and tax rate differentials have replaced exchange rate uncertainty as the prime variable in explaining FDI flows in the new era of globalisation. Should this be the case supported empirically, then it would better explain the current geo-political climate and the move to suppress globalisation in general.

\section{APPENDIX II}

\begin{tabular}{|c|c|c|c|c|c|c|c|c|c|c|c|c|}
\hline \multicolumn{4}{|l|}{ (1) } & \multicolumn{2}{|l|}{ (2) } & \multicolumn{2}{|l|}{ (3) } & \multicolumn{2}{|l|}{ (4) } & \multicolumn{2}{|l|}{ (5) } & \multirow[t]{2}{*}{ (6) } \\
\hline (C) & & & & & & & & & & & & \\
\hline $\begin{array}{l}\text { Belgium-Luxembourg } \\
\text { Italy }\end{array}$ & $\begin{array}{l}-1.2 \\
-0.11\end{array}$ & $\begin{array}{l}(-1.43) \\
(-0.11)\end{array}$ & $\begin{array}{l}-0.53 \\
0.52\end{array}$ & $\begin{array}{l}(-1.3) \\
(0.74)\end{array}$ & $\begin{array}{l}-0.9 \\
-0.003\end{array}$ & $\begin{array}{l}(-0.67) \\
(-0.002)\end{array}$ & $\begin{array}{l}-11.1 \\
13.14\end{array}$ & $\begin{array}{l}(-2.71) \\
(2.31)\end{array}$ & $\begin{array}{l}-0.53 \\
0.82\end{array}$ & $\begin{array}{l}-2.3 \\
(0.9)\end{array}$ & $\begin{array}{l}-1.3 \\
-0.33\end{array}$ & $\begin{array}{l}(-1.3) \\
(-1.02)\end{array}$ \\
\hline Germany & -16.2 & $(-0.8)$ & 0.23 & $(0.94)$ & 1.4 & (1.4) & -8.8 & $(-1.9)$ & 0.22 & (1.12) & 1.27 & $(2.0)$ \\
\hline Netherlands & 5.12 & $(0.68)$ & 0.35 & (2.3) & 1.4 & (2.7) & 1.7 & (4.2) & 0.35 & (2.4) & 1.73 & (4.5) \\
\hline France & 1.1 & 1.3 & 0.1 & $(0.4)$ & 0.27 & 0.29 & 1.43 & $(2.97)$ & 0.024 & $(0.22)$ & 0.86 & (2.2) \\
\hline U.K. & 0.87 & (2.6) & 0.56 & (3.9) & 0.66 & (2.3) & 0.82 & (2.9) & 0.49 & $(4.5)$ & 0.56 & $(2.05)$ \\
\hline \multicolumn{13}{|l|}{$K^{*}(t-1)$} \\
\hline Belgium-Luxembourg & 0.8 & $(2.6)$ & 0.56 & (2.6) & 0.34 & $(2.22)$ & 0.62 & (2.11) & 0.31 & (1.9) & 0.48 & (1.5) \\
\hline Italy & 0.28 & $(0.83)$ & 0.23 & $(0.6)$ & 0.43 & (1.1) & 0.38 & (2.55) & 0.29 & (1.7) & 0.45 & (3.5) \\
\hline Germany & -1.12 & $(-1.5)$ & -0.58 & $(-1.7)$ & -0.46 & $(-1.43)$ & -0.83 & $(-1.9)$ & -0.5 & $(-1.6)$ & -0.23 & $(-1.1)$ \\
\hline Netherlands & -0.08 & $(-0.29)$ & -0.23 & $(-0.92)$ & -0.32 & $(-1.6)$ & -0.4 & $(-2.6)$ & -0.22 & $(0.9)$ & -0.46 & $(-3.7)$ \\
\hline France & -0.81 & $(-1.9)$ & -0.85 & $(-2.5)$ & -0.86 & (1.7) & -1.3 & $(-4.5)$ & -0.75 & $(-3.94)$ & -0.99 & $(-5.2)$ \\
\hline U.K. & -0.1 & $(-1.2)$ & -0.38 & $(-3.5)$ & -0.41 & $(-2.9)$ & -0.04 & $(-0.6)$ & -0.31 & $(-3.25)$ & -0.34 & $(-2.2)$ \\
\hline \multicolumn{13}{|l|}{ (USR) } \\
\hline Belgium-Luxembourg & - & - & 17.0 & (1.1) & 12.2 & $(0.7)$ & - & - & 31.36 & $(2.8)$ & 32.9 & (2.3) \\
\hline Italy & - & - & 6.3 & (0.5) & -2.2 & $(-0.15)$ & 31.8 & $(2.7)$ & 7.6 & (1.4) & - & - \\
\hline Germany & -8.0 & $(-0.3)$ & 11.3 & (1.9) & 17.6 & $(2.7)$ & - & - & 10.22 & (1.86) & 14.7 & (3.7) \\
\hline Netherlands & 3.11 & $(0.28)$ & -2.57 & $(-0.72)$ & - & - & -1.3 & $(-0.7)$ & -2.7 & $(-0.8)$ & - & - \\
\hline France & - & - & 19.35 & (2.3) & 19.2 & $(1.4)$ & - & - & 22.7 & (4.9) & 20.6 & \\
\hline U.K. & - & - & 9.1 & (3.4) & 9.5 & (2.3) & - & - & 7.9 & (3.7) & 8.42 & (2.23) \\
\hline
\end{tabular}


(USY)

\begin{tabular}{lc}
\hline Belgium-Luxembourg & - \\
Italy & - \\
Germany & - \\
Netherlands & - \\
France & - \\
U.K. & - \\
BT & \\
\hline Belgium-Luxembourg & - \\
Italy & - \\
Germany & - \\
Netherlands \\
France \\
U.K. \\
(पBT) \\
\hline Belgium-Luxembourg \\
Italy \\
Germany \\
Netherlands \\
France
\end{tabular}

U.K.

(口)

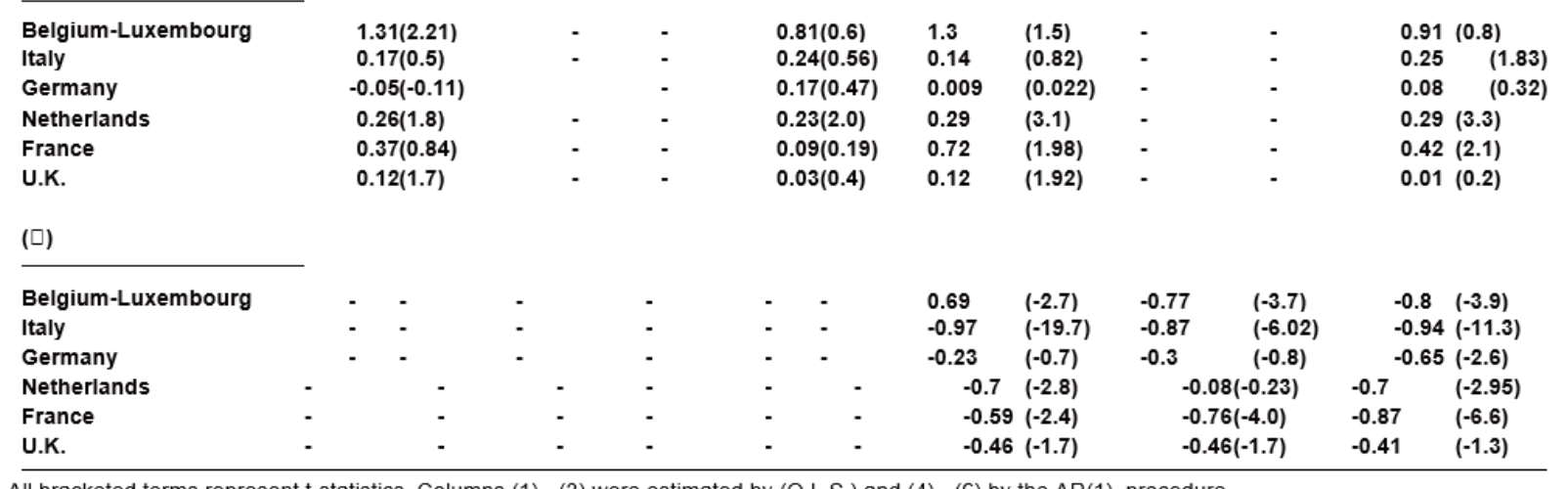

All bracketed terms represent t-statistics. Columns (1) - (3) were estimated by (O.L.S.) and (4) - (6) by the AR(1) procedure.

\section{APPENDIX II}

Data Sources

U.S. Department of Commerce, Survey of Current Business:

$$
\begin{aligned}
& \text { FDI } \\
& K^{*}(t-1)
\end{aligned}
$$

I.M.F., International Financial Statistics:

$$
\text { BT }
$$$$
\square \text { BT }
$$

$e_{t}$

$\mathrm{Ee}_{t}$ 


\section{FOOTNOTES}

(1) Rugman, A.M., Weltwirtschaftliches Archiv, p. 488.

(2) Hartman, D.G., Quarterly Journal of Economics, p. 214.

(3) Agarwal, J.P., Weltwirtschaftliches Archiv, P.747. (4) IBID., p. 750.

(4) IBID., p. 752.

(5) IBID., p. 753.

(6) IBID., p. 761

(7) O.E.C.D.: International Direct Investment and the New Economic Environment: The Tokyo Round Table, p. 31.

(8) Cushman, D.O., Weltwirtschaftliches Archiv, p. 322.

(9) Shapiro, A.C. and C.K. Gamer, Journal of Applied Corporate Finance, p. 10.

(10) Viane, J.M. and C.G. DeVries, Discussion Paper 8905/G, Erasmus University Rotterdam, p. 10.

(11) O.E.C.D.: International Direct Investment and the New Economic Environment: The Tokyo Round Table, p. 22. 


\section{REFERENCES}

GANDOLFO, G., INTERNATIONAL ECONOMICS I, Berlin Heidelberg: Springer-Verlag, 1987.

FRANKELL, J. A., 'Monetary and Portfolio-Balance Models of Exchange Rate Determination', in BHANDARI, J.S. and PUTNAM, B.H. (eds), ECONOMIC INTER-DEPENDENCE AND FLEXIBLE EXCHANGE RATES, Cambridge: MIT Press, 1983.

MEESE, R. A. and K. S. ROGOFF, 'Empirical exchange rate Models of the Seventies: Do they fit out of sample?', JOURNAL OF INTERNATIONAL ECONOMICS, p. 3 (1983)

BOOTHE, P. and D. GLASSMAN, 'Off the Mark: Lessons for Exchange Rate Modelling', OXFORD ECONOMIC PAPERS, p. 443 (1987).

BOOTHE, P. and D. GLASSMAN, 'The Statistical Distribution of Exchange Rates: Empirical Evidence and Economic Implications', JOURNAL OF INTERNATIONAL ECONOMICS, p. 297 (1987).

FLOOD, R. P. and R. M. GARBER, 'Collapsing Exchange Rate Regimes', JOURNAL OF INTERNATIONAL ECONOMICS, p. 1 (1984).

HOOPER, P. and S. W. KOHLHAGEN, 'The Effect of Exchange Rate Uncertainty on the Prices and Volume of International Trade', JOURNAL OF INTERNATIONAL ECONOMICS, p. 483 (1978).

AGARWAL, J. P., 'Determinants of Foreign Direct Investment: A Survey',WELTWIRTSCHAFTLICHES ARCHIV, p. 739 (1980).

RUGMAN, A. M., 'Risk, Direct Investment and International Diversification',WELTWIRTSCHAFTLICHES ARCHIV, p. 487 (1977).

KAWAI, M. and I. ZILCHA, 'International Trade with Forward-Futures Markets Under Exchange Rate and Price Uncertainty', JOURNAL OF INTERNATIONAL ECONOMICS, p. 83 (1986).

HSIEH, D.A., 'The Statistical Properties of Daily Foreign Exchange Rates: 1974-1983', JOURNAL OF INTERNATIONAL ECONOMICS, p. 129 (1988).

VAN NIEUWKERK, M., 'The Covering of Exchange Risks in the Netherlands Foreign Trade', JOURNAL OF INTERNATIONAL ECONOMICS, p. 89 (1979).

BREALEY, R. A. and S. C. MYERS, PRINCIPLES OF CORPORATE FINANCE, Singapore: McGraw-Hill, 1988.

CUSHMAN, D. O., 'Real Exchange Rate Risk, Expectations, and the level of Direct Investment', THE REVIEW OF ECONOMICS AND STATISTICS, p. 297 (1985).

CUSHMAN, D. O., 'Exchange - Rate Uncertainty and Foreign Direct Investment in the United States', WELTWIRTSCHAFTLICHES ARCHIV, p. 322 (1988).

MOLLE, W. T. M. and R. L. A. MORSINK, 'European Direct Investment in Europe', in MUCCHIELLI, J. L. (ed.), MULTINATIONAL FIRMS AND EUROPEAN INTEGRATION, London: Routledge, (Forthcoming).

LEE, W., 'Acquisition par des Societes Etrangeres d'une Partie Importante du Capital de Societes Americaines', INTERNATIONAL BUSINESS LAW JOURNAL, p. 685 (1989).

DE GRAUWE, P., 'Exchange Rate Variability and the Slowdown in Growth of International Trade', INTERNATIONAL MONETARY FUND STAFF PAPERS, p. 63, (1988).

ABUAF, N., 'The Nature and Management of Foreign Exchange Risk', JOURNAL OF APPLIED CORPORATE FINANCE, p. 30 (1986). 
RUTTERFORD, J., 'An International Perspective on the Capital Structure Puzzle', JOURNAL OF APPLIED CORPORATE FINANCE, p. 60 (1985).

SCAPERLANDA, A. E. and L. J. MAUER, 'The Determinants of U.S. Direct Investment in the E.E.C.', THE AMERICAN ECONOMIC REVIEW, p. 558 (1969).

SHAPIRO, A. C, 'International Capital Budgeting', JOURNAL OF APPLIED CORPORATE FINANCE, p. 26 (1983).

SHAPIRO, A. C. and C. K. GARNER, 'A Practical Method of Assessing Foreign Exchange Risk', JOURNAL OF APPLIED CORPORATE FINANCE, p. 6 (1984).

NAUMANN-ETIENNE, R., 'A Framework for Financial Decisions in Multinational Corporations - Summary of Recent Research', JOURNAL OF FINANCIAL AND QUANTITATIVE ANALYSIS, p. 859 (1974).

JUCKER, J. V. and C. DE FARO, 'The Selection of International Borrowing Sources', JOURNAL OF FINANCIAL AND QUANTITATIVE ANALYSIS, p. 381 (1975).

LESSARD, D. R. and D. SHARP, 'Measuring the Performance of Operations Subject to Fluctuating Exchange Rates', JOURNAL OF APPLIED CORPORATE FINANCE, p. 18 (1984).

SHAPIRO, A. C. and B. CORNELL, 'Managing Foreign Exchange Risks', JOURNAL OF APPLIED CORPORATE FINANCE, p. 16 (1983).

HEKMAN, C. R., 'Don't blame currency values for strategic errors: protecting competitive position by correctly assessing foreign exchange exposure', JOURNAL OF APPLIED CORPORATE FINANCE, p. 45 (1986).

LESSARD, D., 'Finance and Global Competition: Exploiting Financial Scope and Coping with Volatile Exchange Rates', JOURNAL OF APPLIED CORPORATE FINANCE, p. 6 (1986)

ALIBER, R. Z., 'The Firm Under Pegged and Floating Exchange Rates', SCANDINAVIAN JOURNAL OF ECONOMICS, p. 309 (1976).

ITAGAKI, T., 'The Theory of the Multinational Firm Under Exchange Rate Uncertainty', CANADIAN JOURNAL OF ECONOMICS, p. 276 (1981).

PRATT, J. W., 'Risk Aversion in the Small and in the Large', ECONOMETRICA, p. 122 (1964).

HARTMAN, D. G., 'Foreign Investment and Finance with Risk', QUARTERLY JOURNAL OF ECONOMICS, p. 213 (1979).

PAGAN, A., 'Econometric Issues in the Analysis of Regressions with Generated Regressors', INTERNATIONAL ECONOMIC REVIEW, p. 221 (1984).

MERTON, R. C, 'Continuous-time Stochastic Models', in EATWELL, J., MILGATE, M. and P. NEWMAN (eds.), THE NEW PALGRAVE: Finance, LONDON: The MacMillan Press Limited, 1989.

HUANG, C. F., 'Continuous-time Stochastic Processes', in EATWELL, J., MILGATE, M. and P. NEWMAN (eds.), THE NEW PALGRAVE: Finance, LONDON: The MacMillan Press Limited, 1989.

NEWBERY, D. M., 'Futures Markets, Hedging and Speculation', in EATWELL, J., MILGATE, M. and P. NEWMAN (eds.), THE NEW PALGRAVE: Finance, LONDON: The MacMillan Press Limited, 1989.

HOUTHAKKER, H. S., 'Futures Trading', in EATWELL, J. MILGATE, M. and P. NEWMAN (eds.), THE NEW PALGRAVE: Finance, LONDON: The MacMillan Press Limited, 1989.

MARKOWITZ, H. M., 'Mean-Variance Analysis', in EATWELL, J.MILGATE, M. and P. NEWMAN (eds.), THE NEW PALGRAVE: Finance, LONDON: The MacMillan Press Limited, 1989.

PRICE, J. A. M., and S. K. HENDERSON, CURRENCY AND INTEREST RATE SWAPS, London: Butterworths, 1984. 
VIANE, J. M. and C. G. DE VRIES, (1989), 'International Trade and Exchange Rate Volatility', Discussion Paper 8905/G, ERASMUS UNIVERSITY ROTTERDAM.

O.E.C.D.: 'International Direct Investment and the New Economic Environment', THE TOKYO ROUND TABLE, PARIS, 1989.

\section{Supplemental Bibliography}

Altshuler, Rosanne and Harry Grubert, Repatriation taxes, repatriation strategies and multinational financial policy, Journal of Public Economics, 2003, 87, 73-107.

Arndt, Christian, Claudia M. Buch and Monika Schnitzer, FDI and domestic investment: An industry-level view, Working Paper, University of Munich, October 2007.

Bhagwati, Jagdish, Arvind Panagariya, and T.N. Srinivasan, The muddles over outsourcing, Journal of Economic Perspectives, Fall 2004, 18 (4), 93-114.

Blanco, Luisa and Cynthia Rogers, Are tax havens good neighbors? An LDC perspective, working paper, Pepperdine University, July 2009.

Desai, Mihir A., C. Fritz Foley and James R. Hines Jr., Chains of ownership, regional tax competition and foreign direct investment, in Heinz Herrmann and Robert Lipsey eds., Foreign direct investment in the real and financial sector of industrial countries (Berlin: Springer Verlag, 2003), 61-98.

Desai, Mihir A., C. Fritz Foley and James R. Hines Jr., Chains of ownership, regional tax competition and foreign direct investment, in Heinz Herrmann and Robert Lipsey eds., Foreign direct investment in the real and financial sector of industrial countries (Berlin: Springer Verlag, 2003), 61-98.

Desai, Mihir A., C. Fritz Foley, and James R. Hines Jr., Foreign direct investment and the domestic capital stock, American Economic Review, Papers and Proceedings, May 2005a, 95 (2), 33-38.

Desai, Mihir A., C. Fritz Foley, and James R. Hines Jr., Do tax havens divert economic activity?" Economics Letters, February 2006a, 90 (2), 219-224.

Desai, Mihir A., C. Fritz Foley, and James R. Hines Jr., The demand for tax haven operations, Journal of Public Economics, March 2006b, 90 (3), 513-531.

Desai, Mihir A., C. Fritz Foley and James R. Hines Jr., Domestic effects of the foreign activities of U.S. multinationals, American Economic Journal: Economic Policy, February 2009, 1 (1), 181-203.

Dharmapala, Dhammika, What problems and opportunities are created by tax havens? Oxford Review of Economic Policy, 2008, 24 (4), 661-679.

Dharmapala, Dhammika and James R. Hines Jr., Which countries become tax havens? Journal of Public Economics, October 2009, 93 (9-10), 1058-1068.

Diamond, Peter A. and James Mirrlees, Optimal taxation and public production, I: Production efficiency; II: Tax rules, American Economic Review, March and June 1971, 61 (1, 2), 8-27, 261- 278.

Dyreng, Scott D. and Bradley P. Lindsey, Using financial accounting data to examine the effect of foreign operations located in tax havens and other countries on US multinational firms' tax rates, Working Paper, Duke University, March 2009.

Faeth, Isabel, Consequences of FDI in Australia - causal links between FDI, domestic investment, economic growth and trade. Department of Economics Research Paper 977, Australian National University, 2006.

Gordon, Roger H. and James R. Hines Jr., International taxation, in Alan J. Auerbach and Martin Feldstein, eds. Handbook of Public Economics, Volume 4 (Amsterdam: North-Holland, 2002), 1935-1995.

Griffith, Rachel and Alexander Klemm, What has been the tax competition experience of the last 20 years? 
Tax Notes International, 28 June 2004, 34 (13), 1299-1315.

Hejazi, Walid and P. Pauly, Motivations for FDI and domestic capital formation, Journal of International Business Studies, May 2003, 34 (3), 282-289.

Hines, James R., Jr., Dividends and profits: Some unsubtle foreign influences, Journal of Finance, June 1996, 51 (2), 661-689.

Hines, James R., Jr., Do tax havens flourish? in James M. Poterba, ed. Tax Policy and the Economy, Volume 19 (Cambridge, MA: MIT Press, 2005), 65-99.

Hines, James R., Jr., Will social welfare expenditures survive tax competition? Oxford Review of Economic Policy, Fall 2006, 22 (3), 330-348.

Hines, James R., Jr. and Eric M. Rice, Fiscal paradise: Foreign tax havens and American business, Quarterly Journal of Economics, February 1994, 109 (1), 149-182.

Hines, James R., Jr. and Lawrence H. Summers, How globalization affects tax design, in Jeffrey R. Brown and James M. Poterba, eds. Tax Policy and the Economy, Volume 23 (Chicago: University of Chicago Press, 2009), 123-157.

Hong, Qing and Michael Smart, In praise of tax havens: International tax planning and foreign direct investment, CESifo Working Paper No. 1942, 2007.

Kaufmann, Daniel, A. Kraay and M. Mastruzzi, Governance matters IV: Governance indicators for 19962004, World Bank working paper, 2005

Keen, Michael J., Vertical tax externalities in the theory of fiscal federalism, IMF Staff Papers, September 1998, 45 (3), 454.

Keen, Michael J., Preferential regimes can make tax competition less harmful, National Tax Journal, December 2001, 54 (4), 757-762.

Keen, Michael J. and Christos Kotsogiannis, Leviathan and capital tax competition in federations, Journal of Public Economic Theory, 2003, 5 (2), 177-199.

Keen, Michael J. and Christos Kotsogiannis, Does federalism lead to excessively high taxes? American Economic Review, March 2002, 92 (1), 363-370.

Klautke, Tina and Alfons J. Weichenrieder, Interest income tax evasion, the EU savings directive, and capital market effects, CESifo Working Paper No. 2300, May 2008.

Kleinert, Jorn and Farid Toubal, The impact of locating production abroad on activities at home: Evidence from German firm-level data, Working Paper, University of Tubingen, 2007.

Kudrle, Robert T., The OECD's harmful tax competition initiative and the tax havens: From bombshell to damp squib, Global Economy Journal, 2008, 8 (1), Article 1, 1-23.

La Porta, Rafael, Florencio Lopez-de-Silanes, and Andrei Shleifer, Government ownership of banks, Journal of Finance, February 2002, 57 (1), 265-301.

Rose, Andrew K. and Mark M. Spiegel, Offshore financial centres: Parasites or symbionts? Economic Journal, October 2007, 117, 1310-1335.

Sharman, Jason C., Havens in a storm: The struggle for global tax regulation (Ithaca, NY: Cornell University Press, 2006).

Sharman, Jason C., Behind the corporate veil: Financial anonymity and crime, Journal of Economic Perspectives, forthcoming.

Simpson, Helen, How does overseas investment affect activity at home? Working paper, University of Bristol, April 2008.

Slemrod, Joel, Why is Elvis on Burkina Faso postage stamps? Cross-country evidence on the 
commercialization of sovereignty, Journal of Empirical Legal Studies, December 2008, 5 (4), 683-712. 